\title{
Regulation in a Multisectored Financial Services Industry: An Exploratory Essay
}

\section{Citation}

Howell E. Jackson, Regulation in a Multisectored Financial Services Industry: An Exploratory Essay, 77 Wash. U. L. Q. 319 (1999).

\section{Published Version}

http://digitalcommons.law.wustl.edu/lawreview/vol77/iss2/3/

\section{Permanent link}

http://nrs.harvard.edu/urn-3:HUL.InstRepos:12956322

\section{Terms of Use}

This article was downloaded from Harvard University's DASH repository, and is made available under the terms and conditions applicable to Other Posted Material, as set forth at http:// nrs.harvard.edu/urn-3:HUL.InstRepos:dash.current.terms-of-use\#LAA

\section{Share Your Story}

The Harvard community has made this article openly available.

Please share how this access benefits you. Submit a story.

Accessibility 


\section{Washington University Law Review}

Volume 77

Issue 2 The Modernization of Financial Services Legislation

1999

\section{Regulation in a Multisectored Financial Services Industry: An Exploratory Essay}

Howell E. Jackson

Follow this and additional works at: http:// digitalcommons.law.wustl.edu/lawreview

Part of the Banking and Finance Commons

\section{Recommended Citation}

Howell E. Jackson, Regulation in a Multisectored Financial Services Industry: An Exploratory Essay, 77 WASH. U. L. Q. 319 (1999). Available at: http://digitalcommons.law.wustl.edu/lawreview/vol77/iss2/3

This work is brought to you free of charge by the Wash U Law Repository. To explore the repository, click here

(http://digitalcommons.law.wustl.edu/). For more information, contact repository@wulaw.wustl.edu 


\title{
REGULATION IN A MULTISECTORED FINANCIAL SERVICES INDUSTRY: AN EXPLORATORY ESSAY
}

\author{
PROFESSOR HOWELL E. JACKSON ${ }^{*}$
}

This Essay reviews differences in regulatory structure across sectors of the financial services industry in the United States and then explores the difficulties these differences pose to our current system of regulation and also to proposals for financial modernization. The Essay begins with a description of a range of financial transactions from simple contracts to pooled investment vehicles to complex financial intermediaries. After reviewing the policy justifications underlying regulation across the financial services industry, the Essay summarizes the distinctive regulatory structures that characterize U.S. oversight of each major sector of the industry: private contract, securities regulation, futures contracts, investment companies, depository institutions, insurance companies, and employee benefit plans. The Essay then reviews the legal definitions that are used to classify which regulatory structure applies to which financial transactions. Distinctions are drawn between formal and functional definitions of financial products, and the Essay claims that functional definitions, which suffer from both overinclusion and indeterminacy, are typically bounded by four types of limitations: de minimus exceptions, sophisticated investor exclusions, institutional carve-outs, and extraterritorial exemptions. The Essay continues to review a series of recent legal disputes in which private parties and government regulators have disagreed over the application of this system of classifying financial products. The Essay then draws some preliminary conclusions as to why disputes over legal classifications of financial products are so common and concludes by exploring the implications of the foregoing analysis for recent proposals to modernize the U.S. system of financial regulation.

This Essay arises out of a larger coauthored project: a legal casebook on

\footnotetext{
* Professor of Law, Harvard Law School. The Harvard Law School Program in Law, Economics, and Business and the John M. Olin Foundation provided funding for the research underlying this Essay. I benefitted greatly from suggestions by Lucian Bebchuk, Tamar Frankel, Louis Kaplow, Cliff Kirsch, Michael Klausner, and Richard Revesz and also from comments of members of the Law and Economics Seminar at Harvard Law School. I also want to express my thanks to my students at Harvard Law School, who contributed greatly to the ideas presented in this Essay.
} 
the Regulation of Financial Institutions, which Ed Symons and I recently completed. ${ }^{1}$ One goal of our casebook was to offer a unified look at the regulation of financial intermediaries in the United States. Whereas prior law school courses and casebooks have focused on separate sectors of the financial services industry-banking, insurance, pensions, mutual funds, and other securities activities - our casebook presents an overview of the broad spectrum of regulation in the financial services industry. One advantage of this structure is that it affords us the opportunity to compare regulatory structures across different sectors of the industry and to consider the implications of the multifaceted regulatory structure that has evolved in the United States.

In this Essay, I attempt to flesh out two of the principal themes introduced in our casebook: first, why the systems of financial regulation differ so substantially across sectors of the financial services industry in the United States and, second, how we should deal with the problems of intersector competition and regulatory arbitrage that our multifaceted system of regulation necessarily invites. These two issues are, in my view, among the central questions now facing policymakers in this field. How should we think about the well-documented fact that banks and insurance companies and securities firms are increasingly in competition with each other? Is this a desirable development that will inevitably lead to better and cheaper financial services for borrowers and savers? Or does the blurring of traditional distinctions in financial forms have a darker side? Should we be trying harder to safeguard the formal regulatory distinctions between banks and insurance companies and securities firms that have evolved over the past hundred years in the United States? Or should we move toward a more functional approach to regulation where legal regimes are determined by the nature of the transaction in question rather than the identity of the intermediary that initiates the transaction? Finally, to the extent we want to move towards a system of functional regulation, what problems can we anticipate in designing and maintaining such a legal structure?

The analysis in the Essay is divided into five Parts. In Part I, I present a spectrum of activities on which I believe most, if not all, forms of financial transactions can be located. I associate various points on this functional spectrum with the essential operations of the most important sectors of our financial services industry: securities transactions, futures trading, mutual funds, depository institutions, and insurance companies.

1. Howell E. JACKSON \& EDWARD L. SyMONS, JR., REgulation OF Financial InstiTUTIONS (1999). To view a website associated with the casebook, see Howell E. Jackson, The Regulation of Financial Institutions (visited June 30, 1999) <http://cyber.harvard.edu/rfi/>. 
In Part II of the Essay, I review the basic policy justifications for the regulation of financial transactions. Although our current regulatory structures advance numerous and sometimes inconsistent public policies, I claim that the most important policy considerations in this field concern the control of risks. There are two basic categories of justification that explain why government-imposed risk regulations are thought necessary for financial transactions. The first set of reasons concern the inability of public investors to negotiate appropriate safeguards on their own behalf. The second set stems from negative externalities associated with financial losses and institutional failures. In each sector, however, there are also secondary policy considerations that do not entail risk regulation and often work at cross purposes to the regulation of risk. These secondary considerations, which I denominate redistributive norms and considerations of political economy, further distinguish regulatory structures across the financial services industry and also further complicate regulatory reform in this field.

Part III of the Essay describes, in very general terms, the principal supervisory strategies that the United States uses to regulate risk in each sector of the financial services industry. My claim in this Part is that, while the primary goal of regulation in each sector is to limit risk taking on the part of financial intermediaries, the regulatory tools used to control risk in each sector differ considerably. To a large degree, these differences reflect functional differences between sectors; to some extent, however, cross-sector variation is also the result of historical evolution and chance. Differences in secondary regulatory policies in each sector-that is, redistributive norms and considerations of political economy-explain other regulatory differences across sectors of the industry. The net result is a series of legal regimes in which the intensity and content of regulatory controls vary greatly across sectors.

Part IV explores the policy implications of the preceding analysis. It considers the regulatory dilemmas presented when functionally similar economic activities - that is, the various sectors of the financial services industry - are governed by different legal regimes. Basic economic theory predicts that under these conditions private actors will try to organize their affairs to be governed by lower-cost regulatory structures. A large amount of activity in the financial services sector over the past twenty years confirms this prediction. Nearly all of the most important interindustry conflicts in the financial services sector over the past thirty years can be characterized as disputes over the appropriate regulatory cubbyhole for some ambiguous financial function. In most of these disputes, the chief legal issue is one of regulatory jurisdiction. In the course of this analysis, I attempt to categorize the ways in which our legal system draws jurisdictional lines between sectors 
and then discuss the incentives of private parties and regulators to manipulate these boundaries.

In Part V, I discuss several recent proposals to restructure our system of financial regulation along more functional lines. After reviewing the basic case for functional regulation, I consider how a system of functional regulation compares to the current structure of financial regulation in this country. In addition, I explore several reasons why reform proposals do not (and should not) pursue the sort of ideal system of functional regulation that some academic theoreticians favor. Rather, I argue, the better path of regulatory reform is one that accepts a more pragmatic and partial codification of the principles of functional regulation.

\section{A TAXONOMY OF FINANCIAL RELATIONS: FROM CONTRACT TO OPAQUE INTERMEDIATION}

One way to conceptualize financial relations is to locate them on a continuum that runs from privately negotiated contractual relationships to what I term fully opaque financial intermediaries. In this Part I sketch out six points on this continuum and offer illustrations of each point in our current financial system.

\section{A. Privately Negotiated Arrangements-Contract}

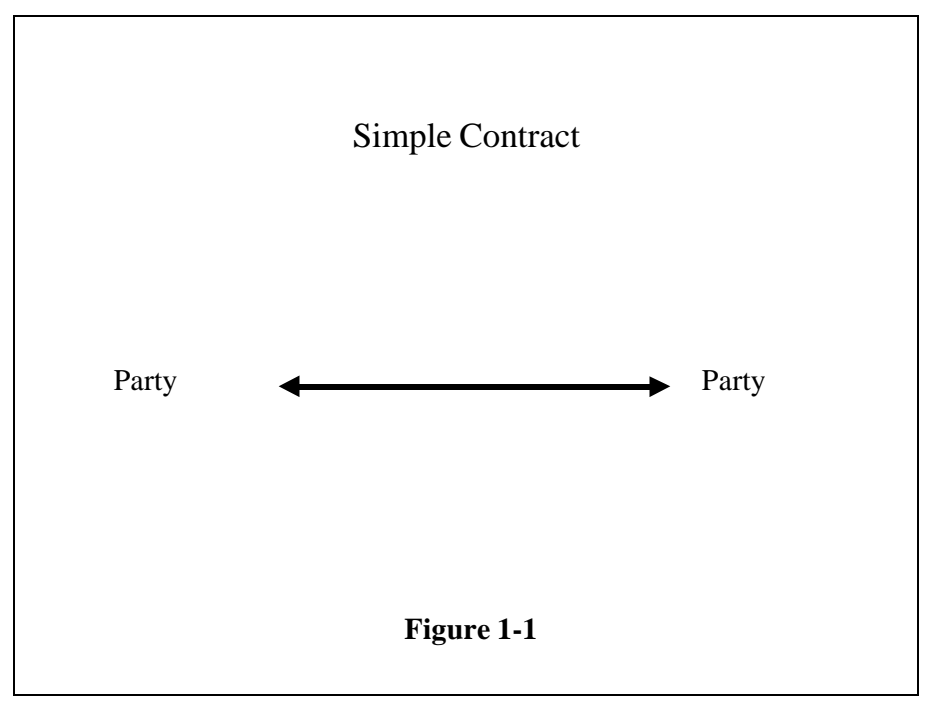

Perhaps the most basic and familiar legal relationship is the simple contract. Through private contract, two or more parties negotiate mutually 
agreeable terms and conditions. Contracts cover a wide range of legal relationships, including many that could be considered primarily financial. For example, loan transactions are largely a matter of private contract, as are custodial arrangements for storing and safeguarding financial resources. Similarly, various kinds of commercial financings-such as deferred payment plans and accounts receivable factoring — primarily take the form of private contract.

While important, the legal structure governing such contractual relationships is minimal, particularly when the contracting parties are commercial entities. Background obligations to perform in good faith and to refrain from affirmative misrepresentations impose some barriers on contracting parties in this country. ${ }^{2}$ But for the most part, the parties are free to set the parameters of their relationship, and legal institutions are available to ensure either performance or damages in the event of breach. ${ }^{3}$

\section{B. Standardized Contracts with Multiple, Unrelated Parties-Securities}

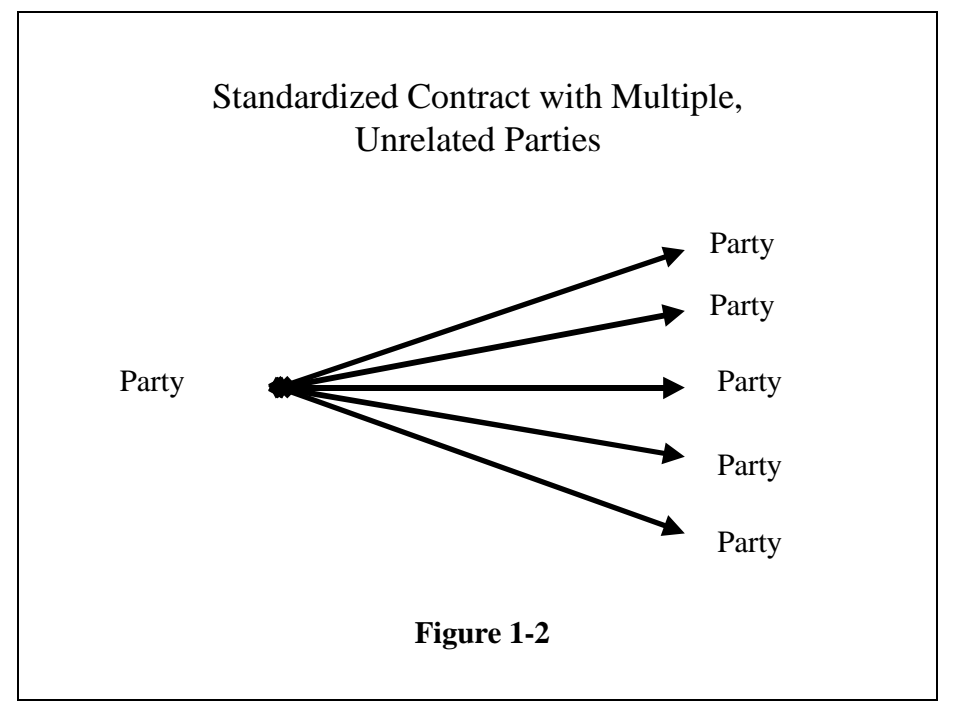

Moving down the spectrum of financial complexity are standardized contracts developed by one or more primary parties for use with multiple,

2. See, e.g., U.C.C. § 1-208 (1989).

3. To be sure, a number of background legal rules, such as the Federal Bankruptcy Code, state laws governing commercial transactions, and even usury restrictions, all serve to limit freedom of contract to some degree. But compared to the regulatory structures governing financial intermediaries, these legal regimes leave much to private ordering. 
unrelated counterparties. Contracts of these sorts exist in many settings. In the market for consumer goods and services, they are sometimes described as contracts of adhesion and are traditionally governed by somewhat more intrusive legal regulation than privately negotiated arrangements. Legislatively and judicially imposed mandatory terms and conditions are often written into such contracts. ${ }^{4}$ Rules of contractual interpretation also differ somewhat for this category of contractual relationship.

On the continuum of financial arrangements, the most common category of standardized financial contract is the security. For both the initial sale of securities by an issuer and the subsequent trading of securities in the secondary markets, our legal rules impose an additional layer of mandatory requirements and legal safeguards. Traditional common-law rules governing fraud are supplemented by more onerous antifraud regimes of modern securities regulation as well as various fiduciary and other safeguards of corporate law. Additionally, a host of mandatory disclosure rules governs issuers of publicly-marketed or publicly-traded securities as well as intermediaries (that is, broker-dealers) who make it their business to facilitate the distribution of and trading in securities.

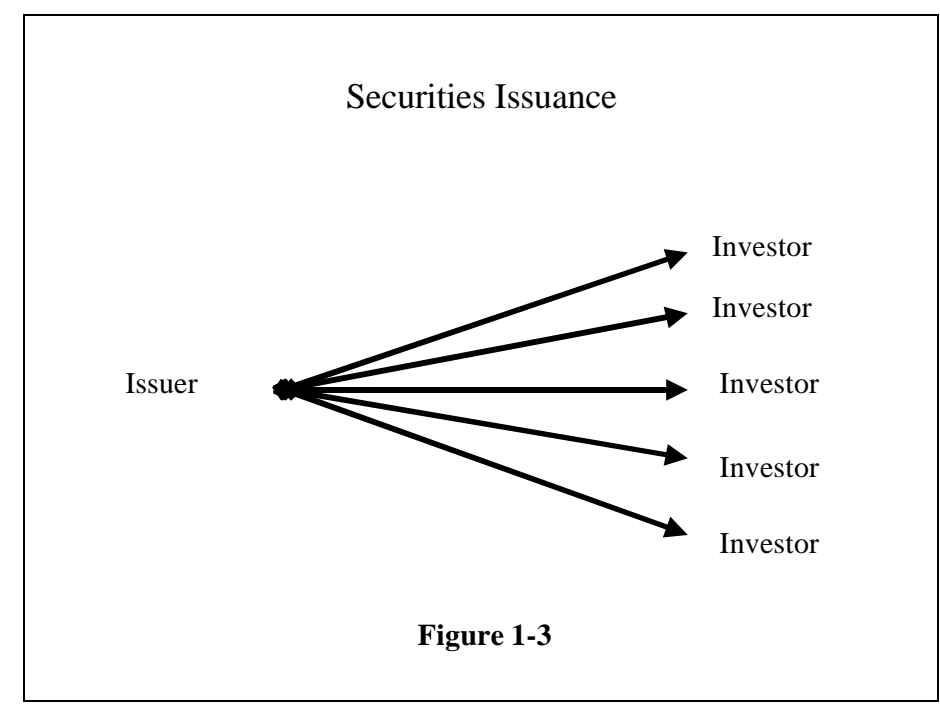

4. See David J. Kaufman, An Introduction to Franchising and Franchise Law, in AN INTRODUCTION TO FRANCHISING AND FRANCHISE LAW (PLI Commercial Law \& Practice Course Handbook Series No. 603, 1992); Todd D. Rakoff, Contracts of Adhesion: An Essay in Reconstruction, 96 HARV. L. REV. 1173 (1983). 
Once a specialized regulatory regime for securities transactions is established, one of the most important jurisdictional boundaries becomes the definition of the term "security." That is the line that determines whether a transaction will be governed by the laissez-faire regime of contract law or the more stringent requirements of securities regulation. Over the past six decades, the U.S. Supreme Court has been called upon to address this issue more than a dozen times. The Court's most important pronouncement on the issue is SEC v. W.J. Howey Co., ${ }^{5}$ in which it attempted to develop a legal standard for determining when business transactions should come under the federal system of securities regulation. The so-called Howey test is often applied in the context of financial intermediaries to determine whether a business dealing constitutes a simple contract or a transaction subject to securities regulation. ${ }^{6}$

\section{Standardized Contracts with Prolonged Duration-Futures Contracts}

Moving further along this continuum of complexity are standardized contracts of prolonged duration. In the financial context, there are two relevant dimensions of duration. One involves the duration of the relationship between an issuer and its security holders. In the United States, this relationship is subject to extensive and continuous regulation whenever the number of securities holders is sufficiently large to bring the issuer within the definition of a public company. ${ }^{7}$ In addition, certain residual antifraud rules apply even if the issuer is not a public firm.

5. 328 U.S. 293 (1946). For a more complete discussion of the Supreme Court's definition of securities cases, see JAMES D. COX ET AL., SECURITIES REgulation: CASES AND MATERIALS 117-209 (2d ed. 1997).

6. See, e.g., Banco Espanol de Credito v. Security Pac. Nat'l Bank, 973 F.2d 51 (2d Cir. 1992) (loan participations as securities), discussed in JACKSON \& SYMONS, supra note 1, at 157-61; Gary Plastic Packaging Corp. v. Merrill, Lynch, Pierce, Fenner \& Smith, Inc., 903 F.2d. 176 (2d Cir. 1990) (brokered deposits as securities).

7. The basic statutory provisions governing when a company must comply with continuous disclosure obligations under federal law can be found in Securities Exchange Act of 1934 $\S \S 12(\mathrm{a}) \&(\mathrm{~g}), 15(\mathrm{~d}), 15$ U.S.C. $\S \S 78 l(\mathrm{a}) \&(\mathrm{~g}), 78 o(\mathrm{~d})(1994)$. Nonpublic companies that make "public offerings" of securities are subject to a separate and shorter regime of regulation under the Securities Act of 1933, 15 U.S.C. $\S \S 77 a-77 z-3$ (1994). 


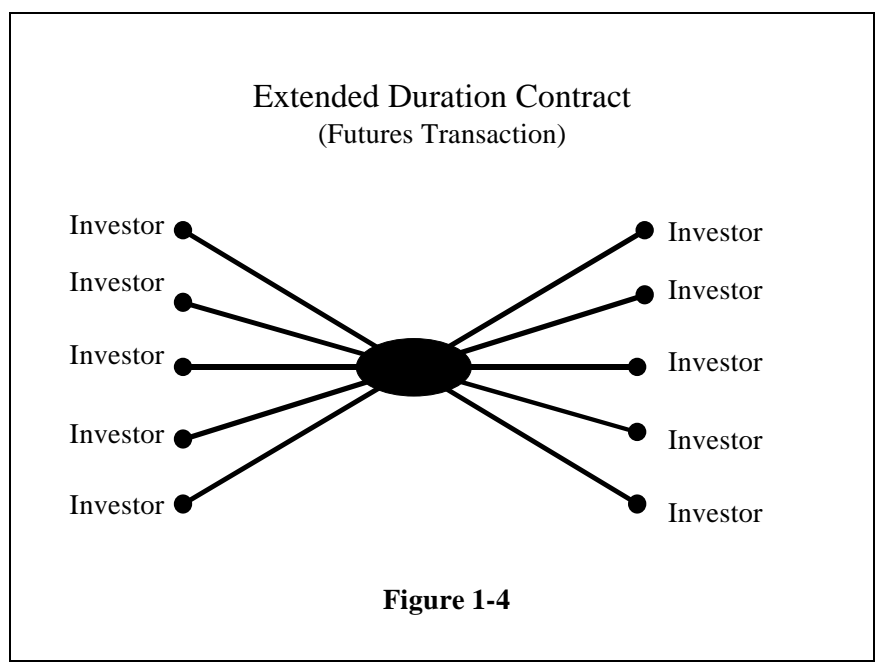

A separate and, for this paper, equally important dimension of duration applies to the secondary market for financial products. In typical secondary market transactions involving securities, the duration of interaction between buyers and sellers of securities is short-term, ending with the settlement of the transaction. ${ }^{8}$ In certain financial transactions, however, the duration of the contractual relationship is much longer. A prime example of such a continuing relationship would be a futures contract, in which two parties have an ongoing obligation with respect to each other. Likewise, options, swap contracts, and various other derivatives contracts have similar characteristics.

To deal with the special problems associated with financial contracts with an extended duration, our legal system has developed various specialized rules governing these transactions. The regulatory system for futures transactions administered by the Commodity Futures Trading Commission ("CFTC") is one illustration of such a regime. ${ }^{9}$ The privately-developed contractual rules governing swap transactions are another illustration. ${ }^{10}$

8. In general, broker-dealers must settle securities transactions with customers within three days in the United States. See Securities Exchange Act of 1934 Rule 15c6-1, 17 C.F.R. § 240.15c6-1 (1998). The relationship between an investor and the investor's securities firm often extends beyond this period if, as is often the case, the broker-dealer holds the investor's securities. In addition, if the investor finances a purchase with a margin loan, the relationship will also continue. See JACKSON \& SYMONS, supra note 1, at 669-74 (summarizing regulatory structure).

9. See Commodities Exchange Act, 7 U.S.C. $\$ \$ 1-25$ (1994).

10. For an introduction to the system, which has evolved with the assistance of the International Swap Dealers Association, see Henry T.C. Hu, Misunderstood Derivatives: The Causes of Informational Failure and the Promise of Regulatory Incrementalism, 102 YALE L.J. 1457 (1993); 
Arguably, our regulatory regimes governing securities trading markets and securities intermediaries provide a third system for the supervision of extended-duration transactions that take the form of options and futures on securities and securities indices. ${ }^{11}$ Thus, our legal system affords three separate legal regimes potentially applicable to financial transaction of extended duration, and a continuing source of controversy in recent years has been over the question as to which legal regimes should apply to particular extended-duration transactions. ${ }^{12}$

\section{Pooled Investment Vehicles-Mutual Funds}

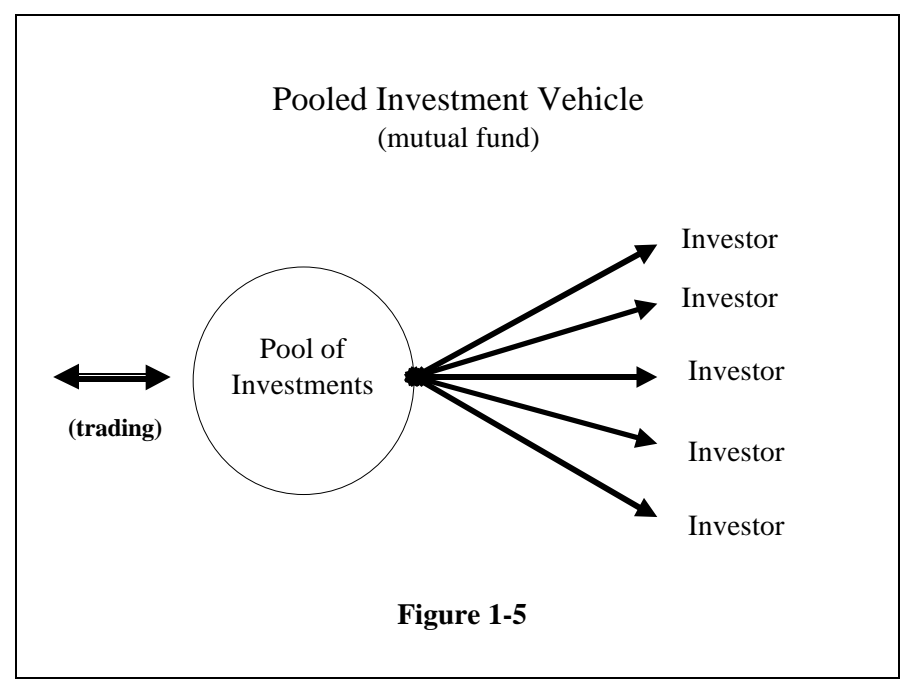

A separate category of financial relationship is the pooled investment vehicle. With this kind of intermediary, investors do not participate directly in the capital markets but rather participate jointly in a pool of investments. In the United States, the most important kind of pooled investment vehicle is

Roberta Romano, A Thumbnail Sketch of Derivative Securities and Their Regulation, 55 MD. L. REv. 1 (1996)

11. Securities trading markets are regulated under various provisions of the Securities Exchange Act of 1934. See JACKSON \& SYMONS, supra note 1, at 751-810.

12. See, e.g., Dunn v. CFTC, 519 U.S. 465 (1997) (considering whether a swap transaction, involving foreign currency, should be subject to CFTC jurisdiction), discussed in JACKSON \& SYMONS, supra note 1, at 1020-32; Chicago Mercantile Exch. v. SEC, 883 F.2d 537 (7th Cir. 1989) (considering whether new financial product with extended duration should be subject to SEC or CFTC jurisdiction), discussed in JACKSON \& SYMONS, supra note 1, at 1008-20. See also, e.g., Procter \& Gamble Co. v. Bankers Trust Co., 925 F. Supp. 1270 (S.D. Ohio 1996) (considering whether swap transactions are securities). 
the open-end investment company (commonly known as a mutual fund), but several other varieties also exist: the common trust, variable annuities, real estate investment trusts, and various pools of securitized assets. The distinguishing characteristic of pooled vehicles is that investors typically share pro rata in ownership of and returns on the pool's assets. As an economic matter, this aggregation of ownership interests allows for various economies of scale (allowing individual investors to share the costs of management expertise and gain access to large denomination investment opportunities) plus a degree of diversification that direct individual investment often will not afford.

The pooled investment vehicle is, of course, simply a specialized type of securities issuer. Unlike ordinary corporate issues, which may engage in various sorts of business activities, pooled investment vehicles limit their activities to investing and trading in securities. Because pooled investment vehicles are typically subject to additional layers of regulatory oversight, there are often legal disputes over when an entity has crossed the line between an ordinary corporation and a more heavily-supervised pooled investment vehicle. ${ }^{13}$

\section{E. Fixed-Return Intermediaries—Depository Institutions}

In this taxonomy, the next station along the continuum of financial complexity is the fixed-return intermediary. It is distinguishable from the pooled investment vehicle in two respects, the most important of which concerns the liability side of the intermediary's balance sheet. Fixed-return intermediaries enter into contractual agreements to pay investors a specified return on their investment. In contrast to investments in pooled vehicles, returns on fixed-return liabilities are not expressly tied to the performance of an intermediary's assets. In the United States, the prototypical fixed-return intermediary is the depository institution: commercial banks, thrifts, and credit unions. All raise funds primarily through fixed-return liabilities.

13. See, e.g., SEC v. Fifth Ave. Coach Lines, Inc., 289 F. Supp. 3 (S.D.N.Y. 1968), aff'd, 435 F.2d 510 (2d Cir. 1970), discussed in JACKSON \& SYMONS, supra note 1, at 839-46. 


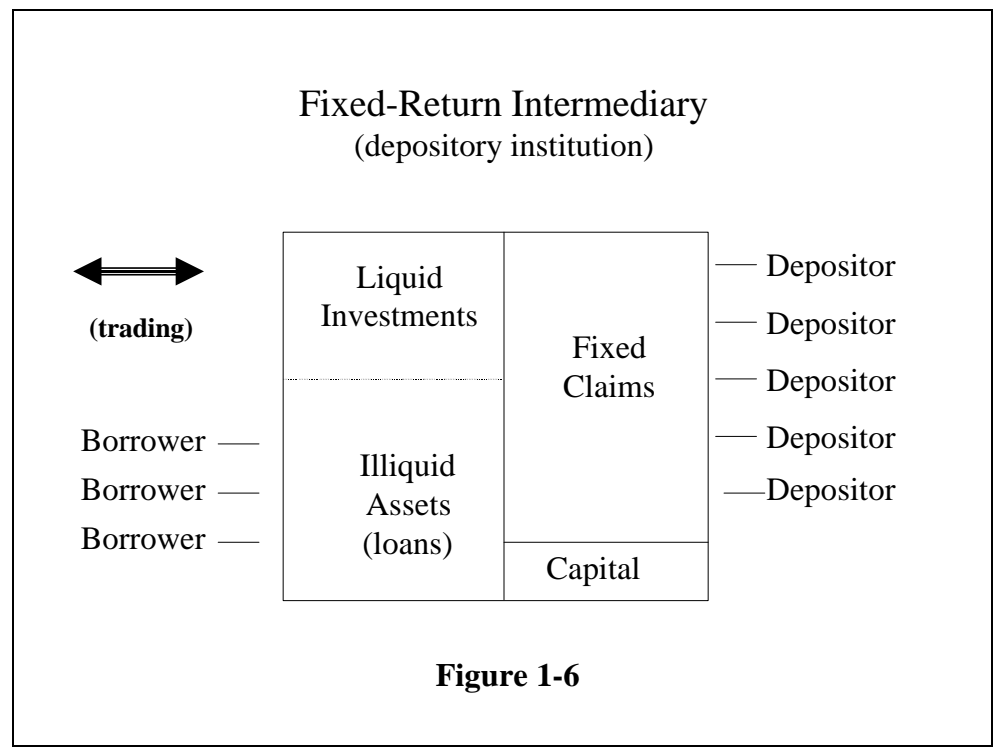

Within the United States and for purposes of this analysis, a second distinguishing characteristic of fixed-return intermediaries is the composition of their assets. While it is possible to construct a fixed-return intermediary that invests solely in liquid securities, ${ }^{14}$ most of our fixed-return intermediaries deploy a substantial portion of their assets into illiquid assets, most notably commercial and consumer loans of various sorts-indeed, by some accounts, the conversion of liquid liabilities into illiquid assets is the defining characteristic of a bank. ${ }^{15}$ Problems related to the illiquidity and proper valuation of many assets held by depository institutions are, therefore, an important fact of life in the regulation of fixed-return intermediaries in the United States. Accordingly, for purposes of this analysis, this fifth paradigmatic financial arrangement is a fixed-return intermediary with at least partially opaque assets. Between this paradigm and the fourth point on the continuum-pooled investment vehicles-one could easily postulate

14. Indeed, a few years ago, a common reform proposal in the United States was to require federally-insured institutions to limit themselves to high-quality marketable investments. See, e.g., ROBERT E. LiTAN, WHAT SHOULD BANKS DO? 164-78 (1987) (recommending narrow banking). Money market mutual funds are effectively regulated in this way. See infra note 83.

15. Economists typically define banks in this way. See, e.g., ZVI BODIE \& ROBERT C. MERTON, FinANCE: PRELIMINARY EDITION 49 (1997) ("Most firms called banks today . . . perform two functions: they take deposits and make loans."). Until 1987, the federal Bank Holding Company Act, relied upon a similar definition of bank. See Bank Holding Company Act, 12 U.S.C. § 1841(c)(1) (1982) (repealed 1987); Board of Governors v. Dimension Fin. Corp., 474 U.S. 361 (1986), discussed in JACKSON \& SYMONS, supra note 1, at 257. 
intermediate cases, such as a pooled vehicle with opaque assets (for example, a REIT) or a fixed-return intermediary with entirely liquid assets (for example, a money market mutual fund). ${ }^{16}$

\section{F. Contingent-Return Intermediaries-Insurance Companies}

The final and most complex category in this continuum includes contingent-return intermediaries. Contingent liabilities differ from fixedreturn deposits or interests in investment pools in that the value of contingent liabilities cannot be determined without reference to unrelated events. In other words, the value of contingent liabilities does not depend on the performance of the issuing intermediary's assets or the terms of the investment contract itself. Fire and life insurance policies are classic examples of contingent liabilities. Liability insurance, title insurance, credit insurance, and a host of other categories of insurance policies also constitute contingent liabilities. Like depository institutions, the principal contingentreturn intermediaries in this country-insurance companies-have traditionally invested a substantial fraction of their assets in illiquid assets. One might therefore, conceive of these institutions as having fully opaque balance sheets. Both the assets and the liabilities of these institutions are difficult to value.

16. A brief aside on off-balance sheets activities is probably in order at this point. Within the United States at least, depository institutions routinely offer various ancillary activities such as: advisory functions, safekeeping and custodial operations, agency activities, and most significantly, payment services, including check writing and electronic funds transfers. The location of these services, and particularly payment services, within the depository institution sector complicates regulation of the field. I do not include these services in my taxonomy of financial functions because in my mind they are not inherently associated with any particular form of intermediation. Payments services, for example, can be associated with investment pools organized as mutual funds. See, e.g., 42 Or. Op. Att'y Gen. 273 (1981) (considering whether a mutual fund with payment services should be deemed to be a bank), discussed in JACKSON \& SYMONS, supra note 1, at 846-50. In addition, specialized payment services are a part of standard brokerage and futures trading accounts. Although not currently available as far as I know, one could also imagine payment services linked to insurance policies with redemption and payment rights.

As discussed below, the provision of many of these ancillary services do present substantial regulatory problems to the extent the provision of these services is subject to additional regulatory structures. Securities advisory and brokerage activities are, for example, ordinarily subject to regulation by the SEC under the Securities Exchange Act and the Investment Advisers Act of 1940. In essence, a fixed-return depository that undertakes such additional activities assumes the role of a securities intermediary and potentially becomes (or should become) subject to additional systems of regulation. But cf. infra text accompanying notes 148-151 (describing bank exemptions from these regulatory requirements under current law). How a regulatory system should deal with entities that assume multiple roles is a topic I address in Part V of this Essay. 


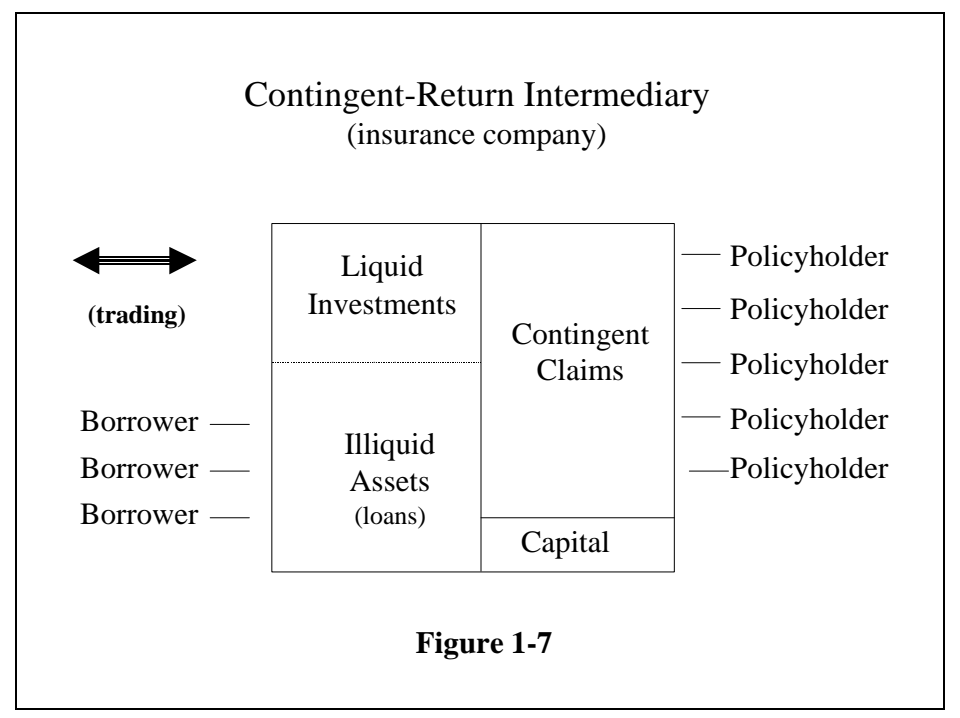

Because the classification of an entity as a regulated contingent-return intermediary-that is, as an insurance company-entails substantial supervisory costs, the law reporters are dotted with illustrations of firms attempting to offer contingent-claim contracts without submitting themselves to regulation as insurance companies. Sometimes these cases involve ordinary corporations proposing to offer their customers various forms of guarantees. ${ }^{17}$ Other times, the transactions involve other types of financial intermediaries offering new products that are functionally equivalent to, if not exactly identical with, insurance policies. ${ }^{18}$ A similar issue arises when employers offer their employees some form of contingent benefit, and the question then arises whether the benefit package is subject to the Employee Retirement Income Securities Act of 1974 ("ERISA"), which is a specialized form of insurance regulation for certain employee benefits. ${ }^{19}$

17. See, e.g., State ex rel. Duffy v. Western Auto Supply Co., 16 N.E.2d 256 (Ohio 1938) (tire warranties), discussed in JACKSON \& SYMONS, supra note 1, at 455-58; Prepaid Dental Servs., Inc. v. Day, 615 P.2d 1271 (Utah 1980) (dental programs), discussed in JACKSON \& SYMONS, supra note 1, at 459-62.

18. See, e.g., First Nat'l Bank of E. Ark. v. Taylor, 907 F.2d 775 (8th Cir. 1990), discussed in JACKSON \& SYMONS, supra note 1, at 462-66; American Deposit Corp. v. Schact, 84 F.3d 834 (7th Cir. 1996), discussed in JACKSON \& SYMONS, supra note 1, at 1140.

19. See, e.g., Massachusetts v. Morash, 490 U.S. 107 (1989), discussed in John H. LANGBEIN \& BRUCE A. WOLK, PENSION AND EMPLOYEE BENEFIT LAW 471-84 (2d ed. 1995). 


\section{PUBLIC POLICIES UNDERLYING THE REGULATION OF FINANCIAL INSTITUTIONS}

One of the striking characteristics of the regulation of the financial services industry in the United States is the fact that while the policies informing regulation across sectors within the field overlap to a considerable degree, the regulatory tools used to pursue those policies differ greatly across sectors. The regulatory structure governing depository institutions, for example, differs significantly from the regulatory structure applicable to investment companies. Likewise, insurance companies have their own peculiar regulatory structures, as do the various subsectors of the securities industry. Exploring why functionally similar entities are subject to such different systems of regulation is the goal of this Part.

Analysis proceeds in three sections. The first describes the most fundamental policy concern that underlies the vast majority of regulatory intervention in this area: the regulation of risk. The next section then explores the variety of overlapping reasons why risk is of central concern in this field and an effort is made to untangle various lines of justification for regulatory intervention. The third section of this Part then reviews several other justifications for the regulation of financial intermediaries that are not directly related to risk or its control.

\section{A. Risk and Its Meaning in the Regulation of Financial Institutions}

In the regulation of financial institutions, risk is a central and, in certain respects, ambiguous concept. To the public's ear, risk is often understood to be a bad thing. And, indeed, if you look the word "risk" up in the dictionary, you find that the first definition given is "the possibility of suffering harm or loss; danger." As an illustration of usage, the American Heritage Dictionary offers: "the usual risks of the desert: rattlesnakes, the heat, and lack of water." ${ }^{20}$ As this example suggests, risk in common parlance is something we discover from the past misfortunes of others, something that we ourselves are advised to avoid, or at least prepare for, in the future. ${ }^{21}$

For the economist and for most policy analysts, however, risk has a quite

20. AMERiCAN HeritAge Dictionary OF THE ENGLiSh LANGUAGE 1557 (1992).

21. The SEC's recent effort to develop standards for risk disclosure for investment companies illustrates the difference between the general public's understanding of risk and the more technical meanings the term has in financial economics. When offered the possibility of reviewing a variety of technical measurements of risk, the SEC discovered the general public preferred simple bar charts that highlight the maximum loss an investor might experience in the course of year. See JACKSON \& SYMONS, supra note 1, at 905-28. 
different meaning. Rather than a collective memory of past bad events, the economist's conception of risk entails a prediction about the future and, in particular, the variation in possible outcomes from a particular activity or course of action. Unlike the lay understanding of risk as danger, the economist sees risk as having both an upside and a downside. An economist thus speaks of Bill Gates's initial investment in Microsoft as having the same amount of ex ante risk as that associated with hundreds of other high-tech startups of the past few decades that have long since dissolved into bankruptcy.

Another important preliminary point to be made about the economist's perspective on risk is its presumed relationship to return. Various foundational theorems of finance postulate-and an extensive body of empirical and anecdotal evidence generally confirms - that as average rates of return on various categories of assets increase so does the risk (or variation in return) associated with those assets. Much of modern financial economics proceeds on the now-familiar assumption that there is a trade-off between risk and return. Implicit within this conception of risk is a policy preference that individuals generally should be given the freedom to make high-risk, high-return investments. For an economist, after all, higher levels of average return are associated with more productive and socially useful investments. While certain individuals, most economists accept, may prefer to place some or all of their assets in low-risk investments, many others will have more tolerance for risk and will want to invest their resources in higher-risk, higher-return projects. On balance, the economist reasons, society will be better off if willing and informed investors are permitted to take on whatever degree of risk they choose.

In some areas of financial regulation, most notably the corporate disclosure rules established in the Securities Act of 1933 and the Securities Exchange Act of 1934, our legal rules generally reflect the economist's bias in favor of investor autonomy. Those laws principally serve to facilitate the disclosure of accurate and complete information about the financial condition and future prospects of public companies. Other areas of financial regulation, in contrast, are characterized by elaborate and overlapping systems of substantive rules designed to restrain risk taking of regulated entities. Through many mechanisms operating at many levels, financial institutions are limited in the amount of risk they can assume and pass on to the general public. I discuss the mechanisms of regulation in Part III of this Essay. In the following section, I explore the justifications for the substantial amount of governmental intrusion to restrain risk taking in this field. 


\section{B. Justifications for the Regulation of Risk in Financial Arrangements}

There are many reasons for our extensive regulation of risk taking by financial institutions. Some concern the kinds of investors that place their funds in financial intermediaries and the limited capacity of these investors to protect themselves when dealing with a financial intermediary.

\section{Protection of Public Investors}

\section{a. Collective Solution to Transaction Costs that Impede Self-Help}

A common explanation of risk regulation in financial intermediaries proceeds on the assumption that public investors in financial intermediaries (that is, depositors, insurance policyholders, and mutual fund shareholders) need some degree of protection from risk taking in financial intermediaries. At a minimum, investors want to know the degree of risk associated with particular investments before they transfer their resources to an intermediary. Ideally, investors also want to gain a sense of how those risks compare with the risks associated with other comparable investments. Equally important, once they make an investment, investors want assurances that the risk profile of their intermediary does not change in a way that disadvantages the investor. Because their individual investments are small and the business of financial intermediation complex, public investors by themselves lack the expertise and incentives to demand appropriate information about the risk profile of financial intermediaries, to decipher that information, or to monitor subsequent behavior on the part of an intermediary. The government, according to this line of reasoning, has a critical role to play in regulating and supervising the risk level of financial intermediaries. Under this view, much of our regulatory structure can be understood as a collective "best guess" regarding the form and content of advance disclosure of institutional risk taking that most investors would demand before making an investment, as well as a continuing set of restrictions on institutional risk taking reflecting a tradeoff between risk and return that most of the investing public would demand from financial intermediaries if the public had the time and expertise to police intermediaries directly. This reasoning justifies government regulation to limit, but not eliminate, financial risk.

\section{b. Absolute Protection of Terms of Investment}

A second justification for risk regulation in financial intermediaries proceeds from a desire to offer complete or near-complete safety for members of the public who invest in financial intermediaries. People who 
make deposits in banks or purchase insurance contracts, it is postulated, generally expect to have those investments honored according to the literal terms of the contracts. In other words, it is assumed, these investors do not want or expect to accept any degree of variation in return on their investments. ${ }^{22}$ Governmental regulation of intermediary operations ensures that the obligations of financial intermediaries are, in fact, honored according to their terms. Government insurance programs, such as those the FDIC operates for depository institutions, also achieve this goal for insured depositors.

\section{Elimination of Externalities from the Failure of Intermediaries}

Other justifications for risk regulation of financial intermediaries focus on possible externalities from risk taking in financial intermediaries. In other words, these justifications proceed on the assumption that public investors may willingly and knowingly place their funds in high-risk intermediaries (presumably in return for the expectation of higher returns). Regulatory justifications that arise out of concerns over externalities are not directly concerned with the losses that a failed intermediary might impose on individuals who have invested funds in that intermediary, but rather with the costs that intermediary's failure might impose on other members of society.

\section{a. The Internalization of Social Losses}

The fiscal ramifications of financial intermediary failures are one sort of externality. The premise here is that the public pays at least partially for intermediary failures, either through underfunded guarantee programs like the now-defunct Federal Savings and Loan Insurance Fund or general welfare programs that have to support individuals who lose resources through intermediary failures. To contain these public costs, the argument runs, the government must constrain risk taking in intermediaries. ${ }^{23}$

22. This justification for risk regulation can be understood as simply an extension of the preceding point: investors are assumed to want complete protection from failure and government policies therefore seek to effect that desire. But there is usually also a paternalistic overlay to this explanation, a notion some financial assets, such as savings accounts, are so important that they should not be exposed to any risks. Elements of the paternalistic justification are also closely related to explanations of risk regulation that are based on concerns of costs that society would assume (through welfare payments or otherwise) if public investors suffer losses on their core savings. See infra Part II.B.2.

23. A well-functioning public insurance system could theoretically force the internalization of these social costs. In practice, however, such insurance systems are hard to implement. Practical and political considerations limit the ability of public regulators to price insurance properly and to create efficient risk classifications. 


\section{b. Systemic Costs of Intermediary Failures}

Another form of externality are systemic costs from financial failure, that is, costs that are transmitted from failed institutions onto other unrelated participants in the economy. Irrational bank runs are perhaps the most common example of systemic costs, but there are other illustrations, including: problems in clearing systems, disruption of capital underwriting, and unexpected contractions of the money supply. Because those injured by systemic costs have no easy way to prevent individual institutions from taking excessive risks and causing uncompensated losses to third parties, the government has another role in regulating financial institutions.

\section{Other Public Policies Underlying Regulation of Financial Intermediaries}

The regulation of risk is not, however, the only public policy underlying the supervision of financial intermediaries. Other public purposes clearly come into play in this field, often at the expense of risk regulation. ${ }^{24}$ While I believe it is fair to elevate risk regulation as the central focus of the regulation of financial institutions, these other policy concerns also play an important role in various sectors of the industry. Differences in the application of other policy considerations across sectors of the industry, moreover, contribute to the complexity of regulating financial institutions. To facilitate subsequent analysis, I divide these other public policies into two basic groups: first, redistributive policies and other equitable norms; and second, considerations of political economy.

\section{Redistributive Policies and Other Equitable Norms}

Though not inherent in the nature of financial intermediation, redistributive policies and other equitable norms are often factored into

24. A recurring tension in the design of financial-institutions regulation is the extent to which other policies should be advanced at the expense of institutional safety and soundness (that is, risk regulation). For instance, in the banking field, liberalization of geographic constraints tends to increase market concentration or threaten anticompetitive goals but is simultaneously thought to improve institutional stability or enhance risk regulation. In the insurance field, rate regulation suppresses price discrimination, thereby distributing wealth from lower-risk to higher-risk policyholders. Nevertheless, the result is often said to diminish insurance company solidity. Similarly, the Community Reinvestment Act is intended to enhance access to credit, yet it is criticized for achieving that goal at the expense of depository-institution safety and soundness. Although the existence and the extent of these tradeoffs is often contested, a common dimension upon which alternative public policies in the area of financial-intermediary regulation are measured is the extent to which they compromise or complicate the fundamental policy of risk regulation. 
financial regulation. Policies of this sort are most apparent in the insurance field, where regulatory systems often restrict the kinds of classifications insurance companies can employ. In the United States, for example, many states prohibit women from being charged lower automobile insurance premiums on the grounds that gender distinctions perpetuate illegitimate stereotypes. ${ }^{25}$ On many other dimensions, insurance companies are precluded from charging actuarially fair rates on the grounds that certain classifications are unfair or unjust. ${ }^{26}$ But redistribution is not the exclusive preserve of insurance regulation. Depository institutions subject to the Community Reinvestment $\mathrm{Act}^{27}$ must comply with statutory obligations to serve the credit needs of low- and moderate-income borrowers in their communities, forcing in effect a cross-subsidization of certain loans. Even in the relatively laissez-faire regime of securities regulation, one can find examples of redistributive policies. ${ }^{28}$ Indeed, once one becomes attuned to the possibility of using financial regulation to effect redistributive goals, examples of the practice abound. $^{29}$

Legal requirements of this sort are not intended to preserve the solvency of financial intermediaries-indeed, at the margin, such requirements probably impair solvency. Rather, their purpose is to achieve various crosssubsidies through the financial system. As discussed in more detail below, the scope and intensity of redistributive policies varies considerably across sectors of the financial services industry. And, as I shall explore in more detail in Part IV of this Essay, variation in the degree of redistributive norms across the industry creates a substantial incentive for firms to recharacterize activities in ways that avoid the costs of complying with regulations designed to implement these policies.

25. See JACKSON \& SYMONS, supra note 1, at 546-50.

26. See id. at 507-31. For a more general discussion of the special policy considerations underlying insurance regulation, see $i d$. at 452-54.

27. See 12 U.S.C. $\$ \S 2901-2906$ (1994), discussed in JACKSON \& SYMONS, supra note 1, at 20924.

28. See JACKSON \& SYMONS, supra note 1, at 755-64 (discussing fixed-commission practices of NYSE, which subsidized smaller and less efficient brokerage houses).

29. Without attempting to be exhaustive, I would count the following regulatory requirements as having substantial redistributive implications: usury rules, which lower interest rates for certain borrowers, see id. at 66-77; activities restrictions for depository institutions, which favor certain investments (for example, commercial loans) over others (for example, junk bonds); risk-based capital requirements for depository institutions, which lower capital costs for favored investments such as mortgages, see id. at 184-209; antidiscrimination rules governing pension plans, which promote retirement savings for lower-income workers through minimum coverage tests, see id. at 612; insurance law rules forcing insurance companies to make local investments, see id. at 580-86; and finally, the Glass-Steagall Act and various other structural restraints, which prevent robust competition among depository institutions, insurance companies, and securities firms, see id. at 1023-1141. 


\section{Considerations of Political Economy}

A final set of justifications for regulation of financial intermediaries are considerations of political economy. The prevention of monopolies is, for example, a goal of many political systems, and antitrust norms are often built into financial regulatory systems, particularly in the area of depository institutions where the public antipathy to concentrations of resources has been particularly acute. ${ }^{30}$ Political factors lead to other structural constraints on the financial services industry. It is, for example, not uncommon for countries to prohibit foreign participation in certain sectors of the financial services industry, ${ }^{31}$ and barriers to internal expansion of financial units also exist. In the field of depository institutions, the Federal Government for many years restricted the interstate expansion of banks. ${ }^{32}$ And, of course, the Glass-Steagall Act and other structural restraints on competition among depository institutions, insurance companies, and securities firms can be understood as expressions of a uniquely American vision of political economy. ${ }^{33}$

One of the peculiarities of the American regulatory structure is that political considerations extend not only to the content of regulatory requirements but also to the identity of those who enforce those regulations. Largely as a result of historical accident, our financial system is built upon a heterogeneous collection of regulatory structures, each with a surprising degree of political resilience within its own traditional sphere of authority. For depository institutions, regulatory authority is divided in the first instance between the states and the Federal Government and then, within the latter category, across a diverse array of federal agencies. ${ }^{34}$ For insurance companies, regulatory authority rests almost exclusively at the state level, ${ }^{35}$ although for pensions and other employee benefit plans, the Federal Government is the exclusive source of regulatory control. ${ }^{36}$ For securities firms, authority is shared between states and the federal Securities and

30. See id. at $86-116$.

31. See id. at 444-45 (describing special rules for foreign and alien insurance companies).

32. See id. at $242-49$.

33. See id. at 1033-41. To be sure, legal restrictions such as the Glass-Steagall Act are also sometimes defended on the grounds that they improve institutional safety and soundness. See infra text accompanying note 84 .

34. See id. at 31-51 (reviewing the history of depository institution regulation in the United States).

35. See id. at 431-42 (reviewing the history of insurance company regulation in the United States). States).

36. See id. at 611-36 (reviewing the history of employee benefit plan regulation in the United 
Exchange Commission ("SEC"), with the latter gaining exclusive powers in several important areas in recent years, ${ }^{37}$ although the SEC still remains without authority over most futures and options markets, which are subject to the supervision of the separate CFTC. ${ }^{38}$

Although many have criticized this haphazard division of regulatory power and pointed with envy to other jurisdictions that have moved in recent years to a more consolidated system of financial regulation, what I wish to emphasize here is that this extreme division of regulatory power in the United States reflects a substantial and enduring fact of political life for our financial regulatory system. One of the realities of our regulatory system is that it is built upon an eclectic collection of supervisory agencies, a substantial number of which are not even creatures of the Federal Government. This further adds to variation in regulatory structure, especially as compared with other jurisdictions that have centralized the supervision of the financial services industry. ${ }^{39}$

\section{Concluding Comments}

While it may be true to say that risk regulation is the primary goal of financial supervision in this field, that fact should not suggest that justifications for regulation are equivalent across the various sectors of the industry. As explored above, there are several different strains of justification for risk regulation. Although investor protection may be a universal norm, not all systems of regulation in the area seek to provide absolute protection of the terms of investment. The threat of various kinds of externalities also differs considerably from sector to sector, and, of course, redistributive policies and considerations of political economy vary considerably across the financial services industry. As explored in the next Part of this Essay, these differences in public policies explain to a large degree the differences in regulatory structures we observe in the financial services industry.

\section{VARIATIONS IN REGULATORY STRATEGIES ACROSS THE FINANCIAL SERVICES INDUSTRY}

For a combination of the foregoing reasons (and to serve various other public goals), the regulation of financial institutions consists of numerous and

37. See id. at 654-64 (reviewing the history of securities firm regulation in the United States); id. at 812-24 (reviewing the history of investment company regulation in the United States).

38. See id. at 1004-32 (reviewing the division of authority between the SEC and the CFTC).

39. See, e.g., William Blair et al., Banking AND FinanCial SeRvices Regulation (1998) (describing consolidation of U.K. regulatory functions in the new Financial Services Agency). 
overlapping strategies designed to constrain the risks associated with financial intermediaries. For purposes of organization, one can divide these regulatory approaches into several general categories: (a) private ordering; (b) disclosure strategies; (c) general standards of conduct; (d) portfolioshaping rules (both static and dynamic); and (e) bonding mechanisms. In this Part, I describe each of these strategies briefly and then discuss the extent to which they are deployed in our current system of regulating financial arrangements.

An important, but not fully developed issue underlying this essentially descriptive exercise is the question why this country uses such radically different regulatory tools to police basically similar financial intermediaries. This is a line of inquiry Professor Symons and I explore at some length in our casebook. To some degree, no doubt, the differences are the product of historical accident and contingent development. ${ }^{40}$ There is, however, some logic to the structure of our regulatory deployment. As a general matter, as the financial arrangements become more complex and the balance sheets of the intermediaries involved become more opaque, our regulatory strategies become more intrusive and draconian. For simpler, more transparent financial relationships, these onerous rules are neither necessary nor costeffective. Accordingly, for simpler arrangements, our system relies on more passive regulatory oversight. In addition, the risks associated with particular financial arrangements also heavily influence the structure of risk regulation. Where the underlying problems are based on transaction costs and collective action problems, more minimal forms of regulatory intervention are often adequate. Where, on the other hand, paternalistic considerations call for absolute protection of public claims or negative externalities motivate legal structures, more intrusive regulatory regimes are typically utilized. Finally, in sectors where redistributive norms and considerations of political economy play a greater role in regulatory design - that is, in the regulation of depository institutions and traditional insurance companies - the intensity of supervisory oversight is increased.

Unfortunately, this part of my Essay is simultaneously lengthy and cryptic. Its length stems from the fact that it summarizes a number of elaborate regulatory structures. It is cryptic because it distills the essential features of those structures into a relatively small space, whereas our casebook treatment of the same subject takes up more than 1100 pages. For readers who find this treatment difficult to follow, I have prepared a table at

40. See supra notes 34-37 (providing cross references to historical reviews of developments of different regulatory systems). 
the end of the section (Table I) where I summarize my descriptive claims. A basic understanding of this summary should allow readers to follow the analysis presented in the balance of this Essay.

\section{A. Private Ordering}

\section{General Description}

A regime of private ordering delegates the responsibility for assigning risk to private parties. The principal advantage of private ordering is that it places the responsibility for risk allocation on the parties with the greatest stake in the proper assignment of risks and the best information about how certain kinds of risk can be reduced. Claims that the private allocation of risk will enhance efficiency and welfare are common in law and economics literature, and are often well-founded.

The preceding discussion of the justifications for regulating risk in the context of financial intermediaries (Part II.B) are, however, essentially arguments why private ordering is not an adequate basis of risk regulation in this context. The presence of significant transaction costs and various kinds of externalities suggest that private ordering is not always an adequate basis for risk regulation in this field. Popular aversion to the imposition of any $e x$ post losses on certain public investors also argues against exclusive reliance on private ordering in the field.

\section{Application to Financial Arrangements}

Private ordering is, of course, our presumptive (but not exclusive) regulatory regime in the field of contracts. In the classic two-party contract setting, we generally allow parties to allocate risks as they choose. Even though these arrangements may have significant financial implications-for example, in the case of long-term supply agreements or construction contracts-we allow parties to allocate risks through conditions to closing and various forms of express representations and warranties. If the financial performance of one party is in doubt, a contractual counterparty cannot usually rely on government safeguards to assure performance but rather must protect itself ex ante by requiring security or prepayment or some form of third-party guarantee. ${ }^{41}$

41. To be sure, the U.C.C. and the Federal Bankruptcy Code, as well as the legal system more generally, are essential to many of the ways in which private parties allocate risk. The point, however, is that the task of invoking these protections is left to private parties and not the province of mandatory 
Even in the contractual setting, however, private ordering is neither absolute nor exclusive. In various categories of private contracts, where serious informational asymmetries or collective action problems plague one side of standardized contracts, government intervention is common. Franchise contracts, for example, are subject to additional legislative safeguards that tend to restrict the bargaining autonomy of private parties, and legal rules governing contracts of adhesion, though largely comprising interpretive norms, also serve to limit bargaining autonomy. ${ }^{42}$ In a sense, securities, futures contracts, and other investments in financial intermediaries discussed in this Essay are simply a subset of financial contracts in which the default contract rule favoring the private allocation of risks does not apply.

The extent to which private ordering survives as a residual tool of risk regulation varies considerably across subsectors of the industry. In designing securities, on the one hand, issuers have considerable autonomy to sculpt individualized terms for priority upon liquidation, redemption rights, conversion features, and interest rates. ${ }^{43}$ Futures contracts are, on the other hand, more severely constrained. The Commodities Exchange Act generally requires both standardized terms and centralized trading on regulated exchanges. ${ }^{44}$ Working down the list of intermediary types, contractual freedom is increasingly limited for mutual funds, depository institutions, and traditional insurance companies. ${ }^{45}$ In dealing with these intermediaries, public investors have very little ability to allocate risks through private arrangements. If they choose to invest in these intermediaries, they must generally accept the terms on which these investments are permitted to be offered and assume the indirect costs of government-imposed regulatory

government regulation.

42. See sources cited in supra note 4 .

43. If the terms become too novel, however, the Securities and Exchange Commission has been known to flex its regulatory muscle-either through denial of acceleration or through unfavorable accounting rulings_-so as to discourage certain features. See, e.g., Securities Act of 1933 Rule 461(b), 17 C.F.R. \$230.461(b) (1998) (outlining conditions under which the Commission may deny acceleration of effective date of a registration statement).

44. See 7 U.S.C. $\$$ 6-24 (1994 \& Supp. III 1997).

45. It is impractical to offer a comprehensive defense of this claim here. Let me simply offer some illustrative restrictions. National banks are, for example, precluded from providing security for most types of deposits. But see 12 U.S.C. § 90 (1994 \& Supp. III 1997), discussed in JACKSON \& SYMONS, supra note 1, at 181-84. Under the 1940 Act, mutual funds are generally prohibited from developing any form of complex capital structure. See Investment Company Act of 1940 \& 18,15 U.S.C. \$ 80a-18 (1994), discussed in JACKSON \& SYMONS, supra note 1, at 949-50.

Under traditional insurance regulation, the form and occasionally even the pricing of insurance contracts are subject to intense regulatory oversight and often prior approval mechanisms. See JACKSON \& SYMONS, supra note 1, at 446-47. The presence of extensive portfolio-shaping rules in these fields precludes depository institutions and insurance companies from engaging in many forms of private ordering. See infra text accompanying notes 84-89. 
controls designed to ensure the safety of their investments.

Private ordering as a mechanism for controlling risk does, however, survive in two revealing aspects of the business of complex financial intermediaries. The first involves contractual arrangements in which public investors do not directly participate and in which concerns over transaction costs and externalities are not squarely presented. So, for example, in the area of depository institutions, lending operations, employment contracts, and supplier relations are typically considered to be standard business contracts and are presumptively the subject of private ordering. ${ }^{46}$ This division of depository institution activities creates, as I will discuss in more detail below, a potential for regulatory arbitrage as banks seek to recharacterize activities as standard (unregulated) business contracts rather than strictly constrained intermediary functions. $^{47}$

A second preserve of private risk allocation is the field of employerprovided fringe benefit plans. Although these private plans are functionally equivalent to specialized insurance companies-spreading, for example, the risk of medical expenses across a pool of employees - the rules governing these plans differ dramatically from those governing traditional insurance companies, particularly in the area of private risk allocation. ${ }^{48}$ For example, traditional insurance companies are often required to include certain kinds of coverage in all health insurance policies, whereas employer-based health care plans are free to structure coverage as they wish. ${ }^{49}$ Similarly, the ability of insurance companies to contract for certain rules of subrogation are often limited by state law, whereas employer-based plans can draft whatever subrogation rules they choose. $^{50}$ Again, this discontinuity in the permissibility of private ordering creates an incentive for private parties to structure risk pooling around an employer-employee relationship governed by ERISA and not around traditional insurance arrangements governed by state law. Not surprisingly, this practice has been a major trend in the

46. Lending operations are, however, the subject of other forms of regulatory control: lending limits and safety-and-soundness considerations. See JACKSON \& SYMONS, supra note 1, at 141-69, 334-49 (lending limit rules and general supervisory powers over bank lending and other activities).

47. One illustration of this point is the effort of depository institutions in the 1970s and early 1980 s to recharacterize deposits as repurchase agreements-that is, to replace regulated fixed liabilities with less-regulated private contractual relationships. "Qualified financial contracts" are another form of transaction that afford banks the ability to negotiate arrangements with counterparties which would not be permitted for traditional borrowers. See 12 U.S.C. § 1821(e)(8)-(10) (1994), discussed in JACKSON \& SYMONS, supra note 1, at 182-83.

48. See, e.g., Einer Elhauge, Allocating Health Care Morally, 82 CAL. L. REV. 1449 (1994).

49. See Metropolitan Life Ins. Co. v. Massachusetts, 471 U.S. 724 (1985), discussed in JACKSON \& SYMONS, supra note 1, at 617-23.

50. See FMC Corp. v. Holliday, 498 U.S. 52 (1990), discussed in JACKSON \& SYMONS, supra note 1 , at 624-29. 
insurance industry since the current regime was adopted in $1974 .{ }^{51}$

\section{B. Disclosure Strategies}

\section{General Description}

In many contexts, including some involving financial intermediaries, disclosure requirements are the strategy of choice for dealing with risk. Mandatory warning labels on products serve to inform consumers of the risks associated with various activities and products. Individuals willing to assume the risks are free to engage in activities regulated in this way, while those adverse to the risks can protect themselves at the outset by avoiding the activities altogether or to some more limited degree. The great advantage of disclosure-based strategies is that they constitute a minimalist form of government intervention. Consumer knowledge is enhanced, while consumer preferences are left largely undisturbed. The drawback of disclosure strategies is that they are inappropriate or ineffective in a variety of contexts. For example, where the disclosure involves information of a highly technical or scientific nature, many consumers will find it difficult to assess the disclosure efficiently and accurately. In dealing with medicines, housing codes, or airline safety records, for instance, few policy analysts would recommend risk regulation based entirely on disclosure. In some contexts where other considerations require information to be kept confidential, disclosure strategies may also be inappropriate.

\section{Application to Financial Arrangements}

There are two ways in which disclosure standards apply to financial arrangements: mandatory disclosure obligations and antifraud rules. Mandatory disclosure obligations impose various duties to release certain information, whereas antifraud rules police the accuracy of statements, whether made voluntarily or in response to mandatory disclosure obligations. In addition to serving the important function of getting critical information to current and potential investors, these rules help investors make meaningful comparisons between the many different kinds of investments.

51. See Gail A. Jensen \& Kevin D. Cotter, State Insurance Regulation and Employers' Decisions to Self-Insure, 62 J. RISK \& INS. 185 (1995). 


\section{a. Mandatory Disclosure}

For what might be considered the middle tier of financial arrangementsdirect investment in securities and intermediated investments through collective investment vehicles-mandatory disclosure obligations are a central risk regulation strategy. The mandatory disclosure obligations imposed on issuers of securities are well-known. For public offerings and firms with large numbers of shareholders, the federal securities laws impose an elaborate system of mandatory disclosure rules. In addition to these periodic reporting rules, the federal securities laws impose a series of special situation disclosure rules, for example, the disclose-or-abstain-from-trading obligations imposed on insiders in possession of material, nonpublic information. Proxy rules and tender offer regulation are also a form of special situation disclosure obligations. The premise of all these mandatory disclosure rules is that in the absence of these rules investors would have inadequate information about the risks associated with particular securities. ${ }^{52}$

Issuer-oriented disclosure does not, however, exhaust the universe of mandatory disclosure rules applicable to the financial services industry. Broker-dealers also face elaborate mandatory disclosure obligations concerning, in particular, compensation, conflicts of interest, and the suitability of investment advice. Even more elaborate mandatory disclosure rules apply to mutual funds. To begin with, mutual funds are subject to all the mandatory disclosure rules applicable to ordinary corporate issuers. In addition, the Investment Company Act of $1940^{53}$ imposes a supplemental layer of disclosure rules designed to address disclosures issues peculiar to

52. For a good overview of the case for mandatory disclosure for corporations, see John C. Coffee, Jr., Market Failure and the Economic Case for a Mandatory Disclosure System, 70 VA. L. REV. 717 (1984)

53. Principal illustrations of the importance of disclosure under the Investment Company Act of 1940 can be found in section 8, 15 U.S.C. $\$ 80 \mathrm{a}-8$ (1994), which establishes the basic registration procedures for investment companies, including specific requirements that investment companies disclose investment policies and other matters of fundamental policy; sections 20, 24, and 30, 15 U.S.C. $\S \S 80 a-20,80 a-24,80 a-29$ (1994 \& Supp. III 1997), incorporating the basic prospectus, annual report, and proxy statement requirements of the federal securities laws, which the SEC has modified to a considerable degree over the past six decades to reflect the specialized disclosure needs of investment companies. See, e.g., Investment Company Act of 1940 Form N-1A, 17 C.F.R. § 274.11A (1998) (basic registration form for open-end investment companies). Securities Act of 1933 Regulation 482, 17 C.F.R. $\$ 230.482$ (1998), is a good example of the many SEC regulations that amplify the Commission's basic disclosure rules to meet the specialized disclosure needs of investors in investment companies. Another recent illustration of this regulatory approach can be found in the SEC staff's recent acceptance of an Investment Company Institute proposal for the development of mutual fund profiles as a supplement of, or posteffective amendment to, more traditional (and more lengthy) disclosure materials. See Letter from Jack W. Murphy, SEC Associate Director and Chief Counsel, to Paul Schott Stevens, ICI General Counsel (July 31, 1995). 
investment pools. $^{54}$

Where mandatory disclosure rules are less common is in the more complex organizational structures of depository institutions, insurance companies, and pension plans. In these contexts, mandatory disclosure is generally thought to be an incomplete regulatory strategy. ${ }^{55}$ Indeed, many of the reasons for regulating risk in the context of financial intermediaries assume public investors cannot or will not correctly process information about risk. In addition, regulatory authorities sometimes fear that certain disclosures could prompt financial panics. While disclosure requirements occasionally supplement financial-institutions regulation, ${ }^{56}$ most regulatory structures for more complex intermediaries rely primarily on other forms of regulation, particularly when risk is the primary source of regulatory concern.

\section{b. Antifraud Rules}

Mandatory disclosure regimes are almost always accompanied by liability rules for material misstatements or omissions; otherwise there is little incentive for regulated parties to comply. In addition, antifraud rules can and do exist in the absence of mandatory disclosure. In this setting, the antifraud rules simply serve to police the accuracy of voluntary disclosures and

54. Given the central importance of disclosure in the regulation of investment companies under the 1940 Act, lawyers in the United States sometimes assume that there is something in the nature of pooled investments that necessitates a disclosure-based regime of regulation. This assumption is not well-founded. Within our own regulatory structure, many other financial products entail pooled investments. With common trust funds at banks, defined-contribution pension plans, and various participating insurance policies investing customers share, pro rata, returns from investment pool investment returns. In none of these other contexts, however, does disclosure regulation play as important a role as it does under the 1940 Act. Bank trust funds and defined-contribution pension plans are regulated primarily through fiduciary rules, whereas participating insurance policies are governed for the most part by portfolio-shaping requirements. But see JACKSON \& SYMONS, supra note 1, at 972-85 (exploring areas in which variable insurance products do become subject to SEC disclosure rules). For an overview of the regulation of bank trust departments, see id. at 224-40. See also Investment Co. Inst. v. Camp, 401 U.S. 617, 642 (1971) (Blackmun, J., dissenting) (discussing similarities between certain bank trust activities and securities transactions), discussed in JACKSON \& SYMONS, supra note 1, at 1040-43.

55. As stated above, regulation of the securities markets is one area in which disclosure is the dominant regulatory form. This statement, however, concerns the SEC regulation of corporate issuers. Capital market participants, such as registered brokered-dealers, are subject to a variety of regulations that go well beyond mere disclosure. The NASD's suitability rules are one example, as are the SEC's net-capital rules for broker-dealers and the SEC's elaborate requirements governing customer securities and the maintenance of SIPC insurance coverage. In addition, market regulation rules promulgated by the SEC and various self-regulatory organizations go well beyond simple disclosure rules. For an overview of these requirements, see JACKSON \& SYMONS, supra note 1, at 669-74.

56. See, e.g., Truth in Lending Act of 1968, 15 U.S.C. \$§ 1601-1667e (1994 \& Supp. III 1997), Truth in Savings Act of 1991, 12 U.S.C. $\$ \$ 4301-4313$ (1994 \& Supp. III 1997), Real Estate Procedures Settlement Act of 1974, 12 U.S.C. §§ 2601-2617 (1994 \& Supp. III 1997). 
representations.

In the context of ordinary bilateral contracts, basic antifraud rules constitute the sole mechanism of disclosure regulation. ${ }^{57}$ Under the doctrine of caveat emptor, parties have no obligation to speak; the speech they undertake, however, is generally subject to basic antifraud protections. Materially untruthful and misleading statements made in connection with private contracts are actionable in this country and serve to police the honesty of private contractual arrangements. Traditionally, however, antifraud provisions at common law and equity were constrained. Privity rules and reliance requirements limited the ability of plaintiffs to recover. And, more importantly, silence was generally not actionable.

The scope of antifraud liability becomes broader and more plaintiff oriented as one moves down the scale of financial complexity into the realm of securities transactions, futures contracts, and investment companies. In the area of securities regulation, all statements made in connection with the purchase and sale of securities are potentially subject to ubiquitous rule 10b-5 liability. ${ }^{58}$ While the U.S. Supreme Court has recently cut back on the scope of rule $10 \mathrm{~b}-5$ liability, ${ }^{59}$ it is still a powerful litigation tool with relatively liberal elements of causation and privity. Other antifraud provisions of the federal securities laws provide even more generous antifraud rules. ${ }^{60}$

For mutual funds, antifraud rules remain an important source of risk regulation. For other intermediaries, however, the strategy is much less prevalent. As mentioned above, mandatory disclosure is not a central regulatory strategy for depository institutions and insurance companies. Supplemental antifraud rules are not much used in these areas either. As a result of a combination of legislative exemptions and favorable court decisions, banks and insurance companies and traditional pension plans are largely exempt from the principal antifraud rules, at least with respect to their traditional products. Private parties generally do not have private rights of action for fraudulent activities on the part of these intermediaries, and public regulators seldom bring enforcement actions based on such theories. ${ }^{61}$

57. To be sure, in some contexts, bilateral contracts are also subject to mandatory disclosure rules. Typically, however, these contexts involve consumer protection issues, where informational asymmetries and collective action problems may exist. As a functional matter, these contexts are more akin to securities transactions than pure bilateral contracts. See supra text accompanying note 4 (discussing standardized contracts with multiple, unrelated parties).

58. 17 C.F.R. $§ 240.10 b-5$ (1994).

59. See Central Bank of Denver v. First Interstate Bank of Denver, N.A., 511 U.S. 164 (1994).

60. In certain securities contexts, liability exists for negligent (as opposed to intentional) misstatements. See, e.g., Securities Act of 1933 § 12(a)(2), 17(a), 15 U.S.C. § 77l(2), 77q(a) (1994 \& Supp. III 1997).

61. Complex intermediaries are, however, required to make certain mandatory disclosures to 


\section{General Standards of Conduct}

\section{General Comments}

A third strategy for constraining institutional risk is the imposition of various general standards of conduct to govern the conduct of firms and individuals involved in the financial services industry. Quite common in the field, these open-ended norms serve as something of a legal way station between disclosure-based regimes described above and more rigid portfolioshaping rules discussed in the next Part. The defining characteristic of openended standards is that they offer no precise guidance as to the scope of their coverage. Typically, these standards are used where regulatory concerns are difficult to define and authorities are unable to articulate a more precise legal requirement. $^{62}$

The fuzziness of open-ended standards is both a strength and a weakness. By relying on vague standards of conduct, governmental authorities need not concern themselves with developing detailed rules that reach every conceivable form of abuse, and indeed, the rules can be enforced to cover conduct that was not even imaginable at the time the standard was promulgated. The vagueness of such standards, however, also creates problems because regulated entities and individuals lack clear guidance as to the scope of legal requirements or prohibitions. As a result, they may refrain from activities that regulatory authority never intended to impede. Vague standards are also susceptible to opportunistic enforcement, either by private parties if private suits are permitted or by unprincipled government officials if administrative enforcement is involved. ${ }^{63}$

public authorities in the context of call reports and related filings, and authorities expend effort policing these filings for accuracy and completeness. See JACKSON \& SYMONS, supra note 1, at 31517 (describing bank reporting and examination). One could, I suppose, characterize the regulators as acting as delegated agents of public investors in these contexts. Accordingly, periodic reporting requirements could be viewed as a substitute disclosure and antifraud strategy. For purposes of this Essay, however, I categorize the examination process as an open-ended standard designed to achieve or prevent certain kinds of conduct. See infra text accompanying note 71.

62. As such, open-ended standards sometimes serve as transitional rules, eventually superceded by more precise mandatory disclosure rules or portfolio-shaping rules, once sufficient regulatory expertise is developed. Examples of this process can be found in the SEC rules on payments for order flow, see JACKSON \& SYMONS, supra note 1, at 796-810, and the evolution of capital standards for depository institutions, see id. at 184-209.

63. The distinction between public and private enforcement could also be used to distinguish regulatory strategies. In gross terms, private enforcement strategies are favored with simpler financial structures, and public enforcement strategies are more important for institutions with more complex structures. The Investment Company Act of 1940 offers something of a mixed case, where a combined strategy is employed. The prevalence of private remedies in simpler structures is sensible and consistent with analysis in this Essay's text because it is in these simpler contexts that investors are 
Another interesting feature of open-ended standards is the manner in which regulated entities bring themselves into compliance. Here, disclosureoriented rules must be distinguished from conduct-forcing standards. For the first category, the standard is satisfied if the regulated party makes appropriate disclosures and receives informed consent. Many traditional fiduciary rules are of this form and are functionally equivalent to vaguely defined mandatory disclosure rules. ${ }^{64}$ The second category of open-ended standards requires compliance and cannot be satisfied through disclosure or consent. Again, one might conceive of this group of rules as portfolioshaping rules with imprecise boundaries.

\section{Application to Financial Arrangements}

Open-ended standards are ubiquitous in the financial services industry. One can, however, make some general comments about the ways in which they are deployed. First, in simpler financial arrangements, the standards tend to be disclosure-oriented rules as opposed to prudential standards of conduct. Second, as the complexity of the intermediaries increases, open-ended norms become of secondary importance and the dominant regulatory mechanism for risk control become more rigid portfolio-shaping rules.

Contracts are the simplest form of financial arrangement, and ordinary bilateral contracts are subject to very few open-ended standards, apart from the U.C.C.'s general requirement that parties proceed in good faith. ${ }^{65}$ There are, however, a subset of bilateral contracts where open-ended standards are common, and that is the traditional trust relationship. (Common trusts, which divide assets between nominal and beneficial ownership, are the simplest form of financial intermediation. ${ }^{66}$ ) As mentioned above, most of trust law is disclosure oriented, and in most contexts is subject to waiver.

In the securities field, open-ended standards are a principal source of regulatory control over the broker-dealer industry. ${ }^{67}$ Fiduciary norms as well

\footnotetext{
most likely to be able to look out for their own interests. Limiting private enforcement to simpler structures does, however, create an incentive for investors to try to recharacterize ex post their relationships with complex intermediaries as "simpler" transactions so as to gain access to private relief. See infra Part IV.B.3.

64. For this reason, in litigation involving broker-dealers, a standard formulation is for the complaining party to characterize the offense as both a violation of fiduciary duty as well as a failure to make adequate disclosure of the conflict. See, e.g., E.F. Hutton \& Co., Exchange Act Release No. 34-25887, 41 S.E.C. Docket 413 (July 6, 1988), discussed in JACKSON \& SYMONS, supra note 1, at 784-95.

65. See U.C.C. § 1-208 (1989) (good faith requirement in sales contracts).

66. See John H. Langbein, The Contractarian Basis of the Law of Trust, 105 YALE L.J. 625

(1995) (describing relationship between fiduciary duties under trust law and disclosure obligations).

67. One reason why fiduciary norms are so important in this area is that other more intrusive
} 
as the National Association of Securities Dealers ("NASD")'s Code of Fair Conduct set general standards for the daily operations of broker-dealers in this country. Violations of these general standards can lead to supervisory action and, in the case of broker-dealers at least, civil litigation. Although many of the standards imposed here are disclosure oriented, some are, in fact if not in form, conduct-forcing standards. For example, the NASD requirement that broker-dealers not charge excessive fees is often described as a simple application of fiduciary law. It is, however, not at all clear that securities firms can meet this requirement by disclosing the amount of their fees and the fact that they are excessive. ${ }^{68}$ Similarly, recently developed rules governing the sale of penny stocks are formulated as disclosure-oriented requirements but have the effect of severely restricting the sale of this kind of security. ${ }^{69}$

The 1940 Act makes even greater use of general standards of conduct. For example, the relationship between an investment company and its investment advisor is expressly fiduciary under section 36(b) of the 1940 Act. ${ }^{70}$ In addition, a basic element of the Act is the requirement that each investment company have a board with a substantial block of independent directors. The Act and its implementing regulations then impose a series of procedural requirements designed to force potentially problematic decisions into the hands of these independent directors and occasionally back out to the fund shareholders themselves. ${ }^{71}$ Without dictating the terms of critical and

forms of intervention are impractical. By its nature, an investment in a security requires the investor to gain or lose based on the security's performance. Open-ended standards employed in this area do not disrupt this relationship. They simply offer some degree of protection concerning the manner in which the public makes its investment decisions and the terms on which those decisions are executed.

68. See, e.g., Hughes v. SEC, 174 F.2d 969 (D.C. Cir. 1949), discussed in Jackson \& Symons, supra note 1 , at $685-88$.

69. See Securities Exchange Act of 1934 Rule 15g-9, 17 C.F.R. $§ 240.15 g-9$ (1998), discussed in JACKSON \& SYMONS, supra note 1, at 721-22.

70. 15 U.S.C. $\$ 80 a-35$ (b) (1994).

71. Illustrations include the following:

The Investment Company Act of 1940 \$ 15(a), 15 U.S.C. § 80a-15(a) (1994), requires that an investment company's two most important service contracts-its advisory contract and its underwriting contract-be approved annually by the board of directors, if not the shareholders themselves.

The Investment Company Act of 1940 § 15(f), 15 U.S.C. § 80a-15(f) (1994), establishes another set of procedural and fiduciary safeguards that come into play whenever an investment advisor attempts to sell or assign its advisory contract. Not only must the new advisory contract be approved by the company's shareholders, but for three years after the assignment at least $75 \%$ of the directors of the company must be independent and the terms of the assignment are prohibited from imposing an "unfair burden" on the company.

The Investment Company Act of 1940 Rule 12b-1, 17 C.F.R. § 270.12b-1 (1998), which establishes rules determining when investment company assets can be used to defray the cost of underwriting fund shares, also relies upon fiduciary oversight by mandating that these arrangements be 
potentially risky transactions (such as the amount of fees paid investment advisers), the 1940 Act "solves" this regulatory problem through open-ended standards.

With the exception of ERISA-regulated benefit plans, open-ended standards exist but are of somewhat less importance in the regulation of more complex financial intermediaries. (As discussed in greater detail below, portfolio-shaping rules are the dominant regulatory form for complex intermediaries). For example, in the area of depository institutions and insurance companies, managers are generally required to protect the safety and soundness of their institutions. Authorities police this general requirement by reviewing call reports and conducting periodic on-site examinations. For banks and insurance companies, these rules are clearly conduct-forcing standard in that prior disclosure seldom offers a defense to enforcement proceedings. ${ }^{72}$

Another common venue for open-ended standards is administrative review and approval procedures. Starting with the broker-dealer industry and extending down through more complex structures, these procedures are fairly common. For broker-dealers, the most important approval procedures come in individual test taking and licensing procedures. The SEC, operating in conjunction with the NASD and state securities commissions, expends considerable effort evaluating applications of individuals who desire to become registered representatives and monitoring individuals' compliance with the applicable legal standards for registered representatives. ${ }^{73}$ To my knowledge, this attention to individual qualifications is unique in the financial services industry and presumably stems from the fact that other more stringent regulatory safeguards (for example, portfolio-shaping rules and bonding mechanisms) are not feasible in the securities industry and less stringent regimes (such as disclosure and antifraud rules) are inadequate. ${ }^{74}$

\footnotetext{
approved by a majority of independent directors of the company and also by establishing special rules to ensure that truly independent directors are appointed.

In all of these contexts, the premise is that fiduciary oversight (policed by the threat of civil suit or supervisory action) is thought to offer a more efficient and effective form of regulation in these areas than other alternatives, such as potentially inflexible portfolio-shaping rules and potentially ineffective disclosure strategies.

72. While legal authorities rarely explain why disclosure should be insufficient in this context, the reason presumably is that the beneficiaries of the rules-depositors, insurance policy holders, and the general public - are not well positioned to give informed consent and, in any event, may have skewed incentives. For discussion of how regulators could be viewed as acting as investors' proxy in this context, see supra note 61.

73. For an overview of these procedures, see JACKSON \& SYMONS, supra note 1, at 669-74.

74. The goal of securities transactions, of course, is to allow investors to participate in the risks of certain investments. In this context, portfolio-shaping rules and bonding mechanisms are largely inappropriate.
} 
Administrative review under prudential standards is common among complex financial intermediaries. A good illustration is the SEC's broad exemptive and interpretive powers under the 1940 Act. Through provisions such as sections 6(c) and 17(b), the SEC has considerable latitude to grant relief from various requirements of the Act. $^{75}$ In most areas, the Commission's exemptive powers are governed by open-ended legal standards, such as "fairness," "reasonableness," and "consistency with the statutory structure."76 For depository institutions and insurance companies, open-ended standards are also written into regulatory approval procedures. So, for example, in ruling on a change-of-control application for banks or registration procedures for a new insurance holding company, the relevant regulatory authorities are required to consider such intangible factors as the quality of management or the business prospects of the applicant. ${ }^{77}$ Insurance statutes also use open-ended standards to review and approve the form and, occasionally, the pricing structure of insurance contracts. ${ }^{78}$ All of these openended standards are conduct inducing in that failure to meet them results in rejection of the application.

\section{Portfolio-Shaping Rules}

\section{General Comments}

Portfolio-shaping rules are another category of risk regulation. These rules generally take the form of specific requirements or prohibitions. As opposed to disclosure-based regulations, which depend upon consumers to absorb and respond rationally to information statements, portfolio-shaping rules entail direct government intervention. Moreover, unlike open-ended standards, portfolio-shaping rules are typically quite formal and explicit. Many of the most common tools of financial regulation are portfolio-shaping rules. Examples include capital requirements, activities restrictions, lending limits, and affiliated transaction rules. Regulations designed to advance redistributive norms or considerations of political economy also tend to take the form of portfolio-shaping rules. ${ }^{79}$

The relatively rigid structure of portfolio-shaping rules is both a strength

75. See 15 U.S.C. $\$ \S 80 a-6(c), 80 a-17(b)$ (1994).

76. See JACKSON \& SYMONS, supra note 1, at 950-56.

77. See Bank Holding Company Act of $1956 \S \S 3,4,12$ U.S.C. $\S \S 1842,1843$ (1994 \& Supp. III 1997), discussed in JACKSON \& SYMONS, supra note 1, at 249-65.

78. See supra note 45.

79. See supra Part II.C.1 (giving illustration of rules that advance redistributive norms or considerations of policy economy). 
and a weakness. The technique is particularly useful where other more flexible forms of regulation, such as disclosure-based consent or bilateral contracting, are ineffective. Portfolio-shaping rules are, however, also likely to be simultaneously overinclusive and underinclusive in constraining risks. They may prevent some desirable activities but at the same time be susceptible to evasion through manipulation or avoidance strategies. For example, under the Glass-Steagall Act, depository institutions are nominally prohibited from entering the securities business, and the Act prevents banks from engaging in some activities that would have net value to society. At the same time, the banking industry has been extremely successful in finding ways around many of the Act's restrictions over the past twenty years and regularly engages in conduct that the legislation was originally understood to proscribe. $^{80}$

\section{Application to the Financial Services Industry}

As a general proposition, portfolio-shaping rules become more common in the financial services industry as the structure of financial arrangements becomes more complex and the ability of public claimants to protect their own interests - either through bilateral contracting, disclosure-based incentives, or policing of fiduciary obligations - becomes more problematic. So, for example, bilateral contracts are subject to virtually no portfolioshaping rules, and in the securities business there are also relatively few portfolio-shaping rules. ${ }^{81}$

The regulation of investment companies in the United States presents an interesting transitional case. As mentioned above, disclosure and fiduciary duties are the dominant regulatory technique for American investment companies. To a certain degree, moreover, the economic function of investment companies limits the role of portfolio-shaping rules in the Investment Company Act of 1940. Investment companies are, by definition, vehicles for pooling the resources of many individuals. As a general matter, the Act does not limit the kinds of investments that individuals can make through the investment company structure. Moreover, the function of investment companies is to allow investors to participate in the performance of the pool, not to insulate the investor for risks associated with the pool. Accordingly, the sort of activities restrictions and capital requirements used in the fields of depository institutions and insurance companies do not map

80. See JACKSON \& SYMONS, supra note 1, at 1033-12 (chronicling erosion of Glass-Steagall Act's barriers).

81. But see supra notes 43,53 (discussing exceptions to this proposition). 
easily onto the investment company structure.

What the Investment Company Act of 1940 does require is that the investment policies of the company be clearly explained in various disclosure documents, and then not changed without advanced approval of a majority of the company's shareholders. ${ }^{82}$ Thus, this portfolio-shaping rule works in tandem with disclosure-based regulation and to a lesser degree fiduciary rules that form the backbone of 1940 Act protections. The 1940 Act's restrictions on changes in investment policies are, however, not the only portfolioshaping rules applicable to mutual funds. Rather, the 1940 Act includes a surprisingly large number of portfolio-shaping rules that serve to reduce certain kinds of risks. Some deal with assets held by investment companies; examples of these provisions are set out in the margins. ${ }^{83}$

Another interesting feature of the Investment Company Act of 1940 is the number of important portfolio-shaping rules that concern the liability side of investment-company balance sheets. ${ }^{84}$ The function of these rules is once

82. For statutory provision governing changes in investment company investment policies, see Investment Company Act of $1940 \S 13,15$ U.S.C. $\S 80 \mathrm{a}-13$ (1994). For a review of disclosure rules applicable to investment companies, see supra note 53.

83. For example, section 12 of the Investment Company Act includes a number of provisions that restrict the kinds of investments an investment company may make. See 15 U.S.C. § 80a-12 (1994 \& Supp. III 1997).

Section 17's rules governing transactions with affiliated parties are another example of portfolioshaping rules. Similar to comparable regimes found in other areas of financial regulation, the section 17 rules are prophylactic standards designed to prevent the sort of insider abuses that plagued the investment company industry in the 1920s and 1930s. See Revisions of Guidelines to Form N-1A, Securities Act Release No. 6927, [1991-1992 Transfer Binder] Fed. Sec. L. Rep. (CCH) II 84,930 (Mar. 12, 1992).

SEC Rule 2a-7, 17 C.F.R. $§ 270.2 \mathrm{a}-7$ (1998), which governs all money market mutual funds, is another example of a portfolio-shaping rule. Here, the SEC regulates with great precision the kinds of investments permissible for this subsector of the industry. In many respects, the money market mutual fund rules are more strict than analogous portfolio-shaping rules in the depository institution and insurance company fields. As a result of this rule, money market mutual funds are almost as safe as federally insured bank deposits. See JACKSON \& SYMONS, supra note 1, at 956-70.

In order to qualify for pass-through taxation treatment under subchapter $M$ of the Internal Revenue Code, U.S. investment companies must also comply with elaborate gross income, diversification, and distribution requirements. For an introduction to these rules, see JAMES E. Hillman, Regulated InVESTMENT COMPANIES (1995). For all practical purposes, these Internal Revenue Code rules dictate the operational policies of investment companies in the United States and strongly influence the shape of their balance sheets.

The 1940 Act also includes a number of related prophylactic standards that go beyond the balance sheet. For example, section 10(a) mandates that at least $40 \%$ of investment company directors be independent and section 17(f) sets forth basic requirements for the use of independent custodians. See 15 U.S.C. $\$ \S 80 a-10(a), 80 a-17(f)$ (1994).

84. Section 18 rules on capital structure are a good case in point. See 15 U.S.C. $§ 80 a-18$ (1994). This provision of the 1940 Act severely limits the amount of leverage investment companies can undertake; moreover, subsection (i) of the provision requires that all management companies limit themselves to a single class of voting stock. More exotic capital structures, which can entail additional risks, are in most circumstances prohibited. 
again largely to facilitate other regulatory strategies. By severely limiting the complexity of mutual fund balance sheets, the 1940 Act makes it easier for shareholders to police the activities of fund managers and, conversely, more difficult for fund managers to behave opportunistically.

The volume and significance of portfolio-shaping rules increases for depository institutions and insurance companies. A classic example of a portfolio-shaping rule would be rules prohibiting a financial institution from investing in stock or engaging in other activities perceived to have a high degree of risk. Thus, the Glass-Steagall Act, which prevents U.S. banks from engaging in a wide variety of securities activities, is a good illustration of a portfolio-shaping rule. ${ }^{85}$ To the same effect are other provisions of U.S. banking law that erect similar barriers to bank expansion into many kinds of insurance underwriting as well as commercial activities more generally. ${ }^{86}$ Insurance companies face comparable restrictions on their investments. ${ }^{87}$

Among more complex intermediaries, portfolio-shaping rules also extend to the liability side of the balance sheet. The liabilities of depository institutions are, for example, subject to some portfolio-shaping rules. While U.S. banks are now generally free to price their deposits as they wish, the collateralization of deposits is generally prohibited, and many deposits have reserve requirements. The form and content of insurance contracts (the principal liability of most insurance companies) are even more heavily regulated. ${ }^{88}$ For banks as well as insurance companies, the most important portfolio-shaping rules are capital requirements, which specify the maximum leverage a depository institution or insurance company can undertake. Capital requirements reduce risk in two ways: they provide a buffer to losses

Section 22's mandatory rules governing the redemption of securities are another important example of portfolio-shaping rules under the 1940 Act. See 15 U.S.C. § 80a-22 (1994). This provision and implementing SEC regulations fix the terms on which and the times at which mutual funds may redeem shares from their investors. Included here are the complex and influential rules governing the calculation of the net asset value of mutual fund shares. In addition, this provision, SEC regulations, and NASD rules establish a general rule of uniform pricing, designed to prevent shareholder losses from dilution and other forms of favoritism.

85. See 12 U.S.C. $§ 24$ (Seventh), 78, 377, 378 (1994), discussed in JACKSON \& SYMONS, supra note 1 , at 1033-35.

86. See JACKSON \& SYMONS, supra note 1, at 265-305 (restrictions on commercial activities); id. at 1113-41 (restrictions on insurance activities of banks).

87. See id. at 445-46 (overview of restrictions on insurance company activities).

88. The reason why insurance company liabilities are more heavily regulated than deposits is that insurance reserves are very difficult to value. Policyholders have a hard time understanding the terms and conditions of their policies, and regulators have trouble valuing the adequacy of insurance company policy reserves. In addition, many of the redistributive norms imposed on insurance companies relate to the structure of insurance policies. See supra text accompanying notes 25,26 . This attention to insurance company liabilities-mostly through various portfolio-shaping rules-make insurance companies the most intensively regulated intermediaries in the United States. 
for depositors and insurance policy holders, and they encourage institution owners and managers to monitor more carefully the activities of their institutions.

Other illustrations of portfolio-shaping regulation are diversification requirements and affiliated-party restrictions. ${ }^{89}$ Both set fixed limits on the kinds of investments financial institutions can make. Diversification requirements-known in the banking field as "loan-to-one-borrower" limits-govern the amount of investment institutions can make to individual borrowers or groups of affiliated borrowers. Affiliated-party restrictions establish stricter guidelines for transactions between financial intermediaries and certain related parties. Like portfolio-shaping rules, diversification requirements and affiliated-party restrictions are prophylactic measures designed to prevent the kinds of investments thought to pose unacceptable degrees of risk. ${ }^{90}$

Though it is beyond the scope of this Essay to explore in any comprehensive way the reasons why portfolio-shaping rules, as opposed to disclosure requirements, figure so prominently in the regulation of insurance companies and depository institutions, one can hazard a few tentative comments. First, public investments in banks and insurance companies are inherently multifaceted. Unlike stocks and bonds, insurance policies and bank deposits are not simply investment vehicles, but they also involve a combination of investment products and ancillary financial services, such as payment services on the part of many bank deposits and risk spreading on the part of insurance policies. The multifaceted nature of the insurance and bank liabilities make disclosure strategies more difficult to implement in these areas. $^{91}$ In addition to the inherent complexity of bank and insurance products, several other factors confound the use of disclosure strategies in these fields. Bank and insurance liabilities are often held by a wide range of

89. In some areas, strict affiliate transactions rules are subject to exception by regulatory waiver. Such waivers are fairly common under the Investment Act of 1940 and for ERISA benefit plans. Elsewhere (for example, in the depository institution field) such waivers are technically available but rarely granted. In the parlance of this Essay, these regimes are hybrid structure-portfolio-shaping rules subject to waiver by administrative procedures based on open-ended standards.

90. In extreme cases, portfolio-shaping rules can extend beyond the legal boundaries of the financial institutions. In the United States, for example, our Bank Holding Company Act replicates for bank holding companies and affiliates many of the elements of risk regulation imposed on banks themselves (for example, activities restrictions and capital requirements). For an extended discussion of the regulation of financial holding companies, see Howell E. Jackson, The Expanding Obligations of Financial Holding Companies, 107 HARV. L. REV. 507 (1994).

91. Indeed, where one sees disclosure-based strategies in the financial services industry (for example, the Truth in Savings Act or the Expedited Funds Delivery Act) the regimes tend to focus on one aspect of the public's relationship with the intermediary, as opposed to the full disclosure approach of SEC rules. 
small public investors, a distribution mechanism that compounds the informational and organizational problems that make it difficult for these investors to fend for themselves. Moreover the assets of these intermediaries, most notably depository institutions, are often illiquid and difficult to value, thus further undermining the effectiveness of disclosure-based regimes. In addition, at least historically, public concern over negative externalities has traditionally been greater for depository institutions and, to a somewhat lesser extent, insurance companies. ${ }^{92}$ Finally, as mentioned above, the presence of more redistributive norms in financial service regulation militate towards a greater reliance on a more interventionist governmental posture, reflected in portfolio-shaping rules.

\section{An Addendum on Dynamic Portfolio-Shaping Rules}

Over the past decade, the trend in the financial services sector has been to move away from static regulatory structures, such as mandatory portfolioshaping rules, and towards somewhat more flexible regimes. In a sense, these dynamic rules attempt to combine the regulatory power of portfolio-shaping rules with the flexibility of open-ended standards. The most prominent example of this trend are "risk-based" capital requirements that vary the amount of capital depository institutions, and increasingly insurance companies, must maintain in order to comply with statutory leverage requirements. ${ }^{93}$ The goal of these risk-based capital requirements is to force riskier institutions to maintain larger capital reserves. Another illustration of dynamic regulations would be the capital-sensitive rules that Congress and federal regulatory agencies have adopted for depository institutions since the late 1980s. These rules permit well-capitalized depository institutions to engage in what are perceived to be more risky, or at least more controversial, activities but deny the same powers to marginally capitalized or inadequately capitalized institutions. The acceptance of brokered deposits, the conduct of

92. With the market break of 1987 and more recent concerns about the integrity of the OTC derivatives markets, however, concerns of systemic risk are increasingly being raised in the context of other kinds of financial arrangements. One consequence of these new concerns has been the introduction of stricter portfolio-shaping rules in areas that have traditionally relied on disclosurebased regulations. As discussed below, this trend is readily apparent in the regulation of money market mutual funds. See infra note 83.

A similar, albeit not yet resolved, discussion is going on in the regulation of OTC derivatives. There the debate is whether OTC derivatives should be brought under the regulatory scrutiny of the Commodity Exchange Act, where mandatory clearing requirements protect investors from the risks of counterparty default. See JACKSON \& SYMONS, supra note 1, at 1020-32. SEC-mandated shortening of settlement periods for securities transactions is an illustration of mandatory terms being tightened in the capital markets. See supra note 8.

93. See JACKSON \& SYMONS, supra note 1, at 184-87. 
nontraditional activities at state-chartered banks, the authority of banks to expand across state lines, even the amount of insurance premiums paid to the FDIC are all, in one way or another, contingent upon the adequacy of an institution's capital reserves. ${ }^{94}$ In a similar vein, innovations in supervisory techniques, such as prompt corrective action rules, mandate increased oversight and diminished operational autonomy for institutions with inadequate levels of capital reserves. Comparable risk-based regulatory rules are also being developed in the field of insurance regulation. ${ }^{95}$

Although there is not room in this Essay to explore in any detail the pros and cons of these dynamic regulatory structures, a brief discussion of their strengths and weaknesses is possible. The insight underlying all these rules is that the amount of regulatory oversight imposed on individual financial institutions should vary based on the level of risks individual institutions undertake. ${ }^{96}$ Thus, well-capitalized institutions are less risky and therefore more capable of bearing the risks associated with nontraditional activities, whereas poorly capitalized institution are prone to risk-taking and failure and thus more deserving of regulatory oversight. Contrary to the one-size-fits-all approach of traditional portfolio-shaping rules, dynamic regulation is custom built for each regulated entity.

On the other side, the most common and important criticism of dynamic regulatory structures is that they all depend on very rough measures of risks. The risk-based capital requirements developed for banks and thrifts in this country divide all assets into four basic risk-weightings designed to reflect the credit risk of particular assets. The classifications are thus very crude-an unsecured line of credit to a start-up business often will receive the same weighting as investment grade commercial paper-and certain kinds of risk (such as interest rate risk) did not even figure into the original risk-based capital calculation. Risk-based calculations also make little effort to reflect the aggregate risks of an institution's portfolio; rather, the rules analyze balance sheets on an asset-by-asset basis, and then aggregate these individual risks to product a final capital requirement. ${ }^{97}$ Another problem with the

94. For a description of these risk-based regimes, see JACKSON \& SYMONS, supra note 1, at 17980 (brokered-deposits); id. at 140-41 (nontraditional activities in state-chartered banks); id. at 246-48 (branching over state lines); $i d$. at 361-63 (prompt corrective action rules). For the FDIC's risk-based insurance premium standards, see 12 C.F.R. $\$ 327.4$ (1998) (rules governing rates of assessment).

95. See JACKSON \& SYMONS, supra note 1, at 444 (risk-based capital requirements for insurance companies).

96. Risk-based regulation can be explained either as an efficient mechanism for allocating regulatory resources to institutions most likely to get in trouble, or as a market-mimicking device designed to force individual enterprises to internalize (through different levels of regulation) the costs associated with their business strategies.

97. In technical terms, what risk-based capital requirements generally fail to consider is the 
current risk-based capital rules is that the dynamic structure of the rules constitutes at best a imprecise regulatory response to the risks that the rules are designed to address. So, for example, the FDIC risk-based insurance premiums charge high-risk institutions a few pennies more for every hundred dollars of insured deposits than low-risk institutions pay. There is little basis for this cost differential, nor is there a firm foundation for other regulatory prescriptions built into the new dynamic regulation structures. (For instance, there is little support for the risk-based capital requirement that commercial loans be supported by twice as much capital as residential mortgages.)

In a crude sense, the 1940 Act has always had elements of dynamic regulation. The regulation structure has from the start distinguished between open-end and closed-end companies, diversified and nondiversified companies, and management companies and unit-investment trusts. The 1940 Act sets different regulatory standards for all of these categories, responding in part to the different kinds of risk associated with different structures. Until quite recently, however, the 1940 Act rules governing various subcategories of investment companies (for instance, the important category of open-end management companies, that is mutual funds) had very few, explicitly dynamic regulations. ${ }^{98}$ More recently, however, the SEC has begun to experiment with more dynamic regulatory structures. ${ }^{99}$

covariance (or interrelation) between various risks.

98. I say explicit here, because the disclosure-based rules built into the Investment Company Act are in some respects analogous to dynamic regulation. The actual information disclosed to investors (such as a fund's investment policies) varies from fund to fund. Indeed, often times the premise of disclosure-based regulation is that investors will be capable of evaluating and acting upon differences in the content of disclosure. In addition, one might consider the SEC's broad exemptive powers to be a crude form of dynamic regulation under which the Commission staff offers exemptive relief on a caseby-case basis.

99. One example of dynamic regulation under the Investment Company Act of 1940 has been the relatively strict set of regulatory rules imposed on money market mutual funds, as opposed to ordinary mutual funds. See SEC Rule 2a-7, 17 C.F.R. § 270.2a-7 (1998); see also supra note 83. The premise of this distinction is that investors in money market mutual funds expect (and are entitled to enjoy) an almost risk-free investment.

Another example of dynamic risk-regulation under the Investment Company Act of 1940 are recent developments in performance reporting. Under the rules adopted by the SEC several years ago, disclosures about the historic performance of mutual funds must be organized under several basic categories of fund types and performance data for individual funds. In essence, these new rules require that historic performance data be presented in a way that makes it easier for investors to compare an individual fund's performance to indices that represent appropriate market averages. This regime, which might best be described as a dynamic disclosure model, varies the content of SEC disclosure rules based on the investment and risk characteristics of mutual fund portfolios.

Hybrid funds, with periodic redemption options, are another illustration of dynamic rules. The SEC has, on a limited number of occasions, allowed such funds to deviate from the daily redemption rules that govern most open-end investment companies. See, e.g., Investment Company Act of 1940 Rule 23c-3, 17 C.F.R. $§ 270.23$ c (1998). 


\section{E. Bonding Arrangements}

\section{General Comments}

A final, and in a certain sense, most extreme risk-reduction strategy consists of various forms of bonding arrangements designed to insulate protected parties from losses, either partially or completely. This approach is typically used in one of two situations: first, when there are strong policy considerations favoring protection of certain classes of claimants; and second, when there are grounds to believe that serious negative externalities might result from claimants suffering losses, and a principal regulatory concern becomes systemic risks to the economy. The problems of bonding arrangements are familiar. Pricing is difficult, and when the government assumes the role of bonding agency, history suggests there is a strong tendency to underprice the bond. Equally important, mandatory bonding arrangements tend to undermine other sources of risk regulation, such as market discipline and other acts of self-help.

\section{Application to the Financial Services Industry}

Bonding arrangements are fairly common in the financial services industry. Government sponsored arrangements exist for depository institutions (the Federal Deposit Insurance Corporation ("FDIC")), insurance companies (various state guarantee funds), and certain pension plan assets (the Pension Benefit Guaranty Corporation ("PBGC")). While the FDIC insurance program was initially designed to deal with the systemic problem of bank runs, over time these major government bonding programs have primarily come to serve the paternalistic function of insulating retail investors and savers from losses. As regulatory strategies, these programs are relatively expensive. For example, early in this decade, average FDIC deposit insurance premiums ( $25 \notin$ per $\$ 100$ of deposits) were equal to more than half of the total operating expenses of many money market mutual funds.

Other forms of bonding arrangements are imposed on the less complex financial arrangements discussed in this Essay. The performance of futures contracts, for example, is guaranteed by regulated exchanges (thus eliminating counter-party risk and whatever systemic consequences it might entail). New $\mathrm{T}+3$ settlement rules for securities transactions-proscribing a three-day period in which securities transactions must settle-perform a somewhat similar function in the capital markets. ${ }^{100}$ Finally, in bilateral

100. See supra note 8. Also applicable to capital markets is the SIPC insurance program, which 
contracts, bonding arrangements in the form of guarantees or standby letters of credit are common risk-reducing devices, albeit created as a result of private ordering.

\section{F. Summary of Analysis}

In an effort to pull together the preceding analysis, I prepared Table I which offers an overview of the structure of regulation of financial intermediaries in the United States. The goal of the Table is to illustrate the basic themes of this section of the Essay: There is a continuum of regulatory strategies from disclosure to open-ended standards to portfolio-shaping rules and bonding requirements, and this continuum maps in a loose sense to the continuum of financial arrangements developed in Part I of this Essay.

The principal exception to this continuum of regulation is the regulation of ERISA plans. Although employee benefit plans are specialized forms of insurance companies, their regulation is distinctive and largely the result of historical accident. As Table I indicates, ERISA regulated plans are subject to fewer portfolio-shaping rules than traditional insurance companies. This is particularly true of employee benefit plans that do not involve retirements savings, where ERISA requirements are particularly lax. ${ }^{101}$ The congressional decision to exempt ERISA plans from state insurance regulation has been the subject of considerable criticism over the past decade. The case against ERISA regulation usually proceeds on the assumption that because employer-provided benefit plans present the same regulatory concerns as traditional insurance companies, the plans should be subject to the same kind of regulation. The defense of ERISA's liberal rules emphasizes that employer-sponsored benefit plans are part of the employer-

protects investors from losses caused by broker-dealer theft but not market movements. See JACKSON \& SYMONS, supra note 1 , at 662-63.

101. To summarize ERISA's regulatory structure quickly, on the asset side, ERISA plans are regulated by fairly strict affiliated party rules (waivable on a case-by-case basis by the Department of Labor) plus prudential investment standards. The liabilities of retirement plans are subject to extraordinarily complex portfolio-shaping rules, designed both to reduce risks and to achieve various redistributive norms. The liabilities of other ERISA plans are not subject to equivalent portfolioshaping rules. In addition, ERISA's bonding mechanism-the Pension Benefit Guaranty Corporation ("PBGC") insurance program-applies only to some retirement plans. As partial compensation for relatively weak portfolio-shaping rules and bonding mechanisms, ERISA does establish fairly broad open-ended standards of conduct (fiduciary rules), most of which are subject to private enforcement. See JACKSON \& SYMONS, supra note 1, at 611-52. See generally LANGBEIN \& WOLK, supra note 19 (excellent introduction to regulation under ERISA). As discussed below, see Table II, infra p. 382, the availability of private rights of action under ERISA occasionally makes it the regime of choice for disgruntled investors. See, e.g., John Hancock Mutual Life Ins. Co. v. Harris Trust \& Sav. Bank, 510 U.S. 86 (1993), discussed in JACKSON \& SYMONS, supra note 1, at 999-1004; cf. supra note 63 (making analogous point about opportunistic use of antifraud provisions of federal securities laws). 


\begin{tabular}{|c|c|c|}
\hline \multicolumn{3}{|c|}{$\begin{array}{c}\text { Table I } \\
\text { Regulation of Financial Institutions in the United States }\end{array}$} \\
\hline \multicolumn{2}{|c|}{ Arrangement } & Overview of Regulatory Regime \\
\hline \multicolumn{2}{|c|}{ Contract } & $\begin{array}{l}\text { - Minimal restrictions on contractual terms and } \\
\text { - } \quad \text { Basic protection from fraud. }\end{array}$ \\
\hline \multicolumn{2}{|c|}{ Securities Transactions } & $\begin{array}{l}\text { - Affirmative duties to disclose in various contexts, } \\
\text { - Strong antifraud protections, } \\
\text { - Some prudential and portfolio-shaping rules } \\
\text { - governing broker-dealers, and } \\
\text { - Supervisory oversight and private enforcement. }\end{array}$ \\
\hline \multicolumn{2}{|c|}{ Futures Contracts } & $\begin{array}{l}\text { - Same basic structure as securities regime; plus } \\
\text { - Mandatory rules governing location and terms of } \\
\text { futures contracts, and } \\
\text { - Performance guaranteed through clearing } \\
\text { arrangements. }\end{array}$ \\
\hline \multicolumn{2}{|c|}{ Mutual Funds } & $\begin{array}{l}\text { - Same basic structure as securities regime; plus } \\
\text { - Increased use of fiduciary protections and } \\
\text { - } \\
\text { Portfolio-shaping rules tailored to enhance } \\
\text { disclosure and fiduciary protections }\end{array}$ \\
\hline \multicolumn{2}{|c|}{ Depository Institutions } & $\begin{array}{l}\text { Portfolio-shaping rules central to regulatory } \\
\text { strategy, } \\
\text { - Disclosure and private rights of action limited, } \\
\text { - Extensive supervisory oversight through } \\
\text { examinations and open-ended review standards, } \\
\text { - Elaborate government guarantees of performance, } \\
\text { and } \\
\text { - Redistributive norms and considerations of } \\
\text { political economy. }\end{array}$ \\
\hline \multirow[t]{2}{*}{$\begin{array}{l}\text { Insurance } \\
\text { Companies }\end{array}$} & Standard & $\begin{array}{l}\text { Same basic structure as depository institution } \\
\text { regime; plus } \\
\text { Considerable regulatory attention to terms of } \\
\text { insurance contracts and valuation of policy } \\
\text { reserves, } \\
\text { - Extensive redistributive and other equitable } \\
\text { norms, and } \\
\text { - Primacy of state regulation. }\end{array}$ \\
\hline & $\begin{array}{l}\text { ERISA } \\
\text { Plans }\end{array}$ & $\begin{array}{l}\text { Some portfolio-shaping rules similar to standard } \\
\text { insurance regulation but more reliance on } \\
\text { fiduciary obligations and fewer mandatory } \\
\text { obligations. }\end{array}$ \\
\hline
\end{tabular}


employee relationship, which is primarily a contractual relationship, policed through bilateral negotiations. ${ }^{102}$ Whatever the merits of the case against ERISA, it is clear that ERISA regulation makes greater use of regulatory strategies common to bilateral contracts and other simpler financial structures than do the regulatory structures applicable to functionally similar insurance companies.

\section{THE CLASSIFICATION PROBLEM}

Upon reviewing Table I, one is confronted with the temptation to consider the wisdom of the regulatory choices the table reflects. Is this deployment of regulatory strategies optimal? Should, for example, we change the way we regulate insurance companies in light of our experiences with depository institutions or mutual funds? Should we move to a more unified regulatory structure? These and other related questions are clearly quite important, but they are not the subject of my analysis here.

What I propose to consider instead is the way in which we police the regulatory divisions implicit in our current structure. How do we make sure that securities transactions are subject to the appropriate securities laws, that contingent claims are governed by insurance or ERISA regulations, and that deposits come under the regulations developed for depository institutions? This is what I term the classification problem. As it turns out, our regulatory structure employs a variety of classification techniques. I review these techniques in section A below.

In section $\mathrm{B}$, I canvass the surprisingly large number of jurisdictional disputes that have plagued the financial services industry in the United States over the past three decades and offer some preliminary explanations about why these disputes have occurred. The received wisdom within the industry and most of the academic community interested in this subject is that these disputes reflect natural, and probably desirable, tendencies on the part of the financial intermediaries to expand their product offerings and increase revenues. My presentation in section B suggests that many of them can also be understood as efforts on the part of private parties to move various kinds of financial arrangements from higher-cost to lower-cost regulatory

\footnotetext{
102. The other common defense of ERISA preemption concerns the desirability of uniform national standards for companies with employees in multiple jurisdictions. The defense, however, does not speak to the content of ERISA regulation and could also be satisfied by a more interventionist national standard. Proponents of national standards, however, tend to prefer bilateral negotiations to police at least some of the risks associated with employee benefit plans.
} 
structures. To a considerable degree, these conflicts are an almost necessary corollary of the multisectored regulatory system we have created in this country.

\section{A. Classifications of Financial Arrangements}

In the United States, the rules governing bilateral contracts constitute the default regulatory structure for financial arrangements. Unless another regulatory structure applies, the presumption is that our lowest cost, least intrusive method of risk regulation applies. In my view, we use two basic classifications systems to assign financial arrangements to regulatory structures: formal definitions and functional definitions, of which the latter category is the more prevalent. Though useful, functional definitions suffer from the serious problems of indeterminacy and overinclusion. As a result, functional definitions of financial activities are typically bounded by a series of exceptions or exclusions, which are discussed separately below.

\section{Formal Definitions of Financial Activities}

Perhaps the simplest way to classify financial arrangements is through a formal definition. In certain regulatory contexts, this is the approach we use. A formal definition creates a regulatory category and typically applies a regulatory standard on an entity that falls within the category. Often times, the category involves the chartering statute under which the entity is organized (for example, all banks organized under the National Bank Act). Formal definitions, however, can also turn on other legal characteristics (for example, all depository institutions with FDIC insurance or all banks that are members of the Federal Reserve System). The hallmark of formal definitions is that they depend on relatively unambiguous legal requirements, and not the sort of precedential or analogical reasoning that characterizes functional definitions.

Formal definitions of the business of banking are typically used in two different contexts. First, they are sometimes used to limit access to some governmental franchise or business privilege. For example, FDIC insurance is statutorily limited to institutions that meet what is primarily a formal definition of banking. ${ }^{103}$ Similarly, access to the Federal Reserve Board's

103. The Federal Deposit Insurance Act ("FDIA") makes federal deposit insurance potentially available to "depository institutions," which are defined to be "any bank or savings association." 12 U.S.C. § 1813(c)(1) (1994). The statute then provides: "The term 'bank'-(A) means any national bank, State bank, and District bank, and any Federal branch and insured branch; (B) includes any former savings association that-(i) has converted from a savings association charter; and (ii) is a 
payments system is restricted to entities meeting another formal definition of banking. ${ }^{104}$ Another illustration would be the regulatory exemptions that the federal securities laws offer entities that meet formal definitions of banking. ${ }^{105}$ Similarly, only investment companies formally registered under the Investment Company Act of 1940 are granted certain privileges under the Internal Revenue Code. ${ }^{106}$

The second common use of formal definitions of banking is to impose statutory obligations on categories of institutions that meet formal statutory requirements. For example, a category of institutions known as "insured depository institutions," that is, banks with FDIC insurance, are subject to numerous regulatory obligations. Such entities must, among other things, meet reserve requirements established under the Federal Reserve Act ${ }^{107}$ and conform to the Community Reinvestment Act of 1977 obligations with respect to the provision of credit to low- and middle-income borrowers. ${ }^{108} \mathrm{~A}$ separate but similarly formal definition of the term "depository institution" describes entities subject to the federal Management Interlocks Act. ${ }^{109}$ Outside of the banking field, formal definitions are used to determine which entities must join the NASD or an SEC-registered securities exchange: any broker-dealer registered with the SEC. ${ }^{110}$

The problem with formal definitions is that they are subject to a high degree of manipulation. Functionally-equivalent products can be developed with different appellations. This problem is particularly acute when the definition is used as a predicate for imposing a regulatory burden, as opposed

Savings Association Insurance Fund member." Id. $\S 1813(\mathrm{a})(1)$. Under this approach, banks are, for the most part, formally defined to consist of entities chartered under enumerated statutory systems. But cf. id. $\S 1813(\mathrm{a})(2)$ (defining term "state bank" to include a functional provision embracing deposittaking entities organized under District of Columbia law).

104. To participate in the Fedwire large-dollar payments system, an institution must meet the formal requirements of having a Federal Reserve account.

105. See Securities Exchange Act of 1933 §3(a)(6), 15 U.S.C. § 78c(a)(6) (1994); Investment Company Act of $1940 \S 2(a)(5), 15$ U.S.C. $\S 80 a-2(a)(5)$ (1994).

106. See 26 U.S.C. $\S 851(a)(1)(A)$ (1994) (definition of regulated investment company).

107. See 12 U.S.C. $\$ 461(b)(1)(A)$ (1994) (reserve requirements).

108. See id. $\$ \S 2901,2902(2)$.

109. The Depository Institution Management Interlocks Act includes the following definition: "[T]he term "depository institution" means a commercial bank, a savings bank, a trust company, a savings and loan association, a building and loan association, a homestead association, a cooperative bank, an industrial bank, or a credit union." Id. § 3201(1) (1994). Upon occasions, the banking agencies have been persuaded to interpreted this definition's reference to "commercial bank" in a functional manner, suggesting that the distinction between formal and functional can at times be blurred. See OCC No-Objection Letter No. 93-01, 1993 OCC Ltr. LEXIS 50 (Aug. 23, 1993) (ruling that CEBA credit card institution owned by Dayton Hudson Corporation should not be considered commercial bank).

110. See Securities Exchange Act of $1934 \S 15(B)(1)(b), 15$ U.S.C. $§ 78 o(b)(1)(B)(1994)$. 
to a prerequisite for obtaining a valuable franchise. For example, in the early 1980s, a number of securities firms developed money market mutual funds with check-writing privileges. Functionally, these products were quite similar to bank deposits, but formally they were specialized investment companies with contractual links to commercial banks that had access to check clearing systems. As long as these entities were not formed as state- or nationallychartered banks, ${ }^{111}$ they were free from a wide range of regulatory structures (and associated costs) that are imposed only on entities formally charted as banks.

Another significant illustration of this phenomenon is the CFTC's jurisdiction over various swap arrangements. Functionally, swaps are equivalent to privately-negotiated futures contracts. If subject to CFTC jurisdiction, however, swaps would be illegal because they are not traded on CFTC-regulated exchanges nor do they comply with a host of additional regulations that govern futures contracts in this country. Accordingly, there has been a decade-long debate over how these instruments should be classified. ${ }^{112}$ The current, somewhat uneasy compromise is to allow them to exist as bilateral contracts, protected principally through privately negotiated risk-sharing mechanisms. ${ }^{113}$

A final formal definition that became the subject of widespread avoidance was the old Bank Holding Company Act definition of a bank: (1) any entity that "accepts deposits that the depositor has a legal right to withdraw on demand; and (2) engages in the business of making commercial loans." 114 Until the provision was amended in 1987, the financial services industry flouted the Bank Holding Act by creating "nonbank banks" that either did not accept demand deposits or did not make commercial loans. ${ }^{115}$

111. An Oregon Attorney General opinion, 42 Or. Op. Atty Gen. 273 (Feb. 11, 1981), discussed in JACKSON \& SYMONS, supra note 1 , at 846-50, concluded that these arrangements should not be considered the business of banking and thus did not force the entities involved to be organized as formally chartered banks.

112. For an introduction to this controversy, see Dunn v. CFTC, 519 U.S. 465 (1997), discussed in JACKSON \& SYMONS, supra note 1, at 1023-32.

113. When the party to a swap is a regulated entity, such as a commercial bank or insurance company, the entity's regulatory structure may indirectly police swap risks, but when counter parties are unregulated, only basic contractual protections apply.

114. 12 U.S.C. $\$ 1841$ (c) (1982) (repealed 1987). One could, I suppose, argue that this is a more functional definition, since it depends on whether an entity engages in certain activities. But the activities were interpreted in such a narrow manner that the definition became quite formal and, as a result, quite susceptible to manipulation.

115. See Board of Governors v. Dimension Fin. Corp., 474 U.S. 361 (1986), discussed in JACKSON \& SYMONS, supra note 1, at 256-57. 


\section{Functional Definitions}

More sophisticated and flexible than formal definitions are functional approaches to defining regulatory jurisdiction. ${ }^{116}$ A good example of a functional definition is one used to define the jurisdictional boundaries of the federal securities laws, which potentially apply to any transaction involving a "security." 117 In addition to a few dozen illustrative examples, the statutory definition of the term includes "investment contracts," which the courts have interpreted to mean "a contract, transaction or scheme whereby a person invests his money in a common enterprise and is led to expect profits solely from the efforts of the promoter or a third party." 118 Over the years, this definition has been interpreted to embrace a wide variety of multiparty investment relationships. In disputes arising under this definition, the creator of the disputed transaction is typically arguing that the arrangement should be treated as a simple contract (where antifraud rules are more lenient) as opposed to a security (where rule 10b-5 and the duty to be truthful in all material respects apply). ${ }^{119}$ Sometimes the party that initiated the transaction is already regulated under one regulatory regime, and the question is whether federal securities laws should also extend to the transaction in question. ${ }^{120}$

Functional definitions are used to establish the jurisdictional boundaries of most of the regulatory systems discussed in this Essay. For example, under section 3(a) of the Investment Company Act of 1940, any entity that invests or proposes to invest more than forty percent of its total assets in securities is presumptively subject to 1940 Act regulation. ${ }^{121}$ The definition extends not just to entities operating in corporate form, but includes partnerships, trusts, and other less formal legal structures. ${ }^{122}$ Most insurance company statutes

116. Clearly, the line between formal and functional definitions is not always bright. Formal definitions are often based on somewhat functional understandings of the meaning of words. In this analysis, formal definitions are short conclusory definitions, whereas functional definitions are definitions that propose a number of characteristics to define a classification.

117. See Securities Act of 1933 \&2(a)(1), 15 U.S.C. § 77b(a)(1) (1994 \& Supp. III 1997); Securities Exchange Act of 1934 § 3(a)(10), 15 U.S.C. § 78c(a)(10) (1994).

118. SEC v. W.J. Howey Co., 328 U.S. 293, 299 (1946).

119. This was the context of the classic Supreme Court precedent, SEC v. W.J. Howey Co., 378 U.S. 293.

120. See, e.g., Banco Espanol de Credito v. Security Pac. Nat'l Bank, 973 F.2d 51 (2d Cir. 1992) (bank-originated loan participations were not "securities"), discussed in JACKSON \& SYMONS, supra note 1, at 158-61; SEC v. Variable Annuity Life Ins. Co., 359 U.S. 65 (1959) (variable insurance products as securities), discussed in JACKSON \& SYMONS, supra note 1, at 972-85; International Bhd. of Teamsters v. Daniel, 439 U.S. 551 (1979) (pension benefits were not securities), discussed in JACKSON \& SYMONS, supra note 1, at 985-1004.

121. See SEC v. Fifth Ave. Coach Lines, Inc, 289 F. Supp. 3 (S.D.N.Y. 1968), aff'd, 435 F.2d 510 (2d Cir. 1970), discussed in JACKSON \& SYMONS, supra note 1, at 838-46.

122. See Prudential Ins. Co. v. SEC, 326 F.2d 383 (3d Cir. 1964), discussed in JACKSON \& 
have a similar structure. A typical insurance statute would govern all transactions in which "one party . . . is obliged to confer benefit of pecuniary value upon another party ... dependent upon the happening of a fortuitous event in which the [second party] has ... a material interest which will be adversely affected." 123 Another illustration of a functional approach to jurisdiction is the manner in which ERISA defines who should be regulated as a plan fiduciary: any one that "controls" plan assets, renders paid investment advice to a plan, or has "discretionary authority" over plan administration. ${ }^{124}$

Another prominent example of functional definitions can be found in the foundational elements of American banking law: state prohibitions on unauthorized banking. These statutes typically prohibit unregulated entities from engaging in the business of banking. Illustrative of such prohibitions is Texas Finance Code section 31.004(a), which provides: "Except as otherwise provided by law, a person other than a depository institution authorized to conduct business in this state may not conduct the business of banking or represent to the public that it is conducting the business of banking in this state." ${ }^{125}$ The premise underlying these provisions is that an entity should not be allowed to engage in the business of banking unless the entity complies with the regulatory safeguards designed to restrain the risks associated with depository institutions and also presumably complies with the social obligations and political constraints imposed on the banking industry.

While the policies motivating such statutes are clear, the scope of their application often is not. It is not uncommon for an individual or organization to resist the assertion that it is engaged in the business of banking. In response to such disputes, courts and regulatory agencies have developed an extensive set of precedents in this area. While there is considerable variation in the manner in which the business of banking is defined from jurisdiction to jurisdiction, the courts and agencies generally identify a set of "core" banking activities and then inquire whether the entity in question is

SYMONS, supra note 1 , at 980-85.

123. ARK. CODE ANN. § 23-60-102(1)(A)(i) (Michie 1987 \& Supp. 1997). But see First Nat'l Bank of Eastern Ark. v. Taylor, 907 F.2d 775 (8th Cir. 1990) (holding debt cancellation contracts were not insurance and were not subject to state insurance regulation), discussed in JACKSON \& SYMONS, supra note 1 , at 462-66.

124. See ERISA § 3(21)(A), 29 U.S.C. § 1002(21)(A) (1994), discussed in JACKSON \& SYMONS, supra note 1 , at 993-1004.

125. See also MASS. GEN. LAWs ch. 167, § 37 (1996) ("No domestic or foreign corporation or individual . . . shall conduct the business of a savings bank, co-operative bank, savings and loan association, credit union, trust company or banking company unless authorized to do so under the laws of this commonwealth"), interpreted in First Fidelity Corp. v. Commissioner of Banks, 684 N.E.2d 1, 3 (Mass. App. Ct. 1997). 
sufficiently engaged in those core activities to be deemed in the business of banking. ${ }^{126}$

The great advantage of functional definitions, as compared to formal ones, is that they allow jurisdictional lines to track more closely the policies that motivate our regulatory structures. So, for instance, the purpose of the 1940 Act is to protect investors who place their financial resources in investment pools, and the section 3(a) definition reviewed above provides a fairly simple definition of an investment pool-a legal entity with a substantial percentage of its assets allocated to investment securities. Similarly, the goal of insurance regulation is to police the issuance of contingent promises, and the jurisdictional provision excerpted above embodies that concept. In addition, the basic definitions of broker and dealer under the Securities Exchange Act of 1934 are designed to extend our federal system of regulating brokers and dealers to all those engaged in the regular business of buying and selling securities, either for their own account or for the account of customers. ${ }^{127}$

In practice, however, an important problem of functional definitions is

126. Typical of this approach is State ex rel. Taylor v. Currency Service, Inc., 218 S.W.2d 600 (Mo. 1949), in which the Missouri Attorney General argued that the respondent corporation was engaged in the unauthorized business of banking because it was selling bonded money orders and "post-card" checks issued by third party banks. To resolve this dispute, the court reviewed a statutory list of banking activities and then considered whether respondent's activities were functionally equivalent to the enumerated banking powers. While respondents' check-selling activities were functionally similar to certain enumerated bank powers, they constituted only a small portion of the business of a traditional bank's operations, and the court was unwilling to classify the firm as engaged in the business of banking as a result of this isolated activity. See id.

More recently, the Texas Attorney General took much the same approach in response to the request of the Texas Banking Commissioner that a university debit card program be classified as an unauthorized banking business. See Tex. Op. Att'y Gen. DM-239 (Mar. 9, 1995), discussed in JACKSON \& SYMONS, supra note 1, at 122-27. Under the program, students and staff deposit funds with the University and received in return a debit card that could be used to purchase services from the University and vendors operating concessions on campus. In response to the Commissioner's argument that the University must be engaged in the business of banking because it was accepting deposits as part of its debit card program, the Attorney General reasoned as follows:

"Historically a bank merely served as a place for the safekeeping of the depositors' money and even now that is the primary function of a bank. The term 'bank' now by reason of the development and expansion of the banking business does not lend itself to an exact definition."

Furthermore, authority from other jurisdictions suggests that an entity is not necessarily a bank just because it engages in certain acts that are typical of banks; rather one must look at the activities of the entity as a whole. We do not believe that a court would conclude that a university that offers a debit card program such as the one you describe among its many and various activities engages in banking.

Id. (quoting Breham Prod. Credit Ass'n v. Zeiss, 264 S.W.2d 95, 97 (Tex. 1953)) (internal citations omitted).

127. See Securities Exchange Act of 1934 3(a)(4), (a)(5), 15 U.S.C. § 78c(a)(4), (a)(5) (1994), discussed in JACKSON \& SYMONS, supra note 1, at 675. 
that they are overinclusive and indeterminate. Let me begin with overinclusion: Take the basic 1940 Act definition of investment company. Though at first blush a perfectly reasonable definition of an investment pool, it turns out that it picks up a wide variety of economic relationships to which we most likely would not want to apply 1940 Act restrictions. ${ }^{128}$ Examples include corporate holding companies (like GM or IBM), start-up entities holding investment securities for a short period of time until they can be invested in capital assets, and banks, insurance companies, and pensions, all of which regularly invest more than forty percent of their assets in securities of one sort or another. Section 3(a)'s definition presumptively brings all these entities under the control of the 1940 Act. Functional definitions of insurance have similar problems. It turns out that in many transactions one party makes a pecuniary commitment to another party based on fortuitous events that cause harm. Express warranties in standard contracts often have precisely this function, and there is a long line of definition-of-insurance cases in which the courts attempt to distinguish between real warranties and disguised insurance contracts. $^{129}$

A review of recent cases confirms my assertion regarding the indeterminacy of functional definitions. As explained in greater detail in the next section of this Essay, the courts have been inundated in the past few decades with litigation in which one party claimed an activity constituted a certain type of financial arrangement while the opposing party asserted it was another. So, for example, when a national bank wanted to get into the life insurance business a few years ago, it offered its customers loans with "debt cancellation" provisions under which the bank would forgive the loan in the event the borrower died while the loan was outstanding. In ensuing litigation, the local insurance commissioner took the view that these arrangements constituted insurance transactions, whereas federal banking regulators sanctioned the activity as reasonably incidental to banking. ${ }^{130}$ Faced with such disputes, courts typically attempt to determine the predominant characteristic of the transactions in question-for example, whether the activity had more in common with the business of banking or more in common with insurance- and then classify the transaction accordingly. But

128. See JACKSON \& SYMONS, supra note 1, at 839-46.

129. See Douglas v. Dynamic Enters., Inc., 869 S.W.2d 14 (Ark. 1994) (interpreting the Arkansas provision cited above, ARK. CODE ANN. § 23-60-102(1) (Michie 1987 \& Supp. 1997), to embrace a used-car warranty); see also State ex rel. Duffy v. Western Auto Supply Co., 16 N.E.2d 256 (Ohio 1938), discussed in JACKSON \& SYMONS, supra note 1, at 455-58.

130. See First Nat'l Bank of E. Ark. v. Taylor, 907 F.2d 775 (8th Cir. 1990) (siding with federal authorities, but largely on preemption grounds as opposed to substantive analysis of contracts in question), discussed in JACKSON \& SYMONS, supra note 1, at 462-66. 
this sort of balancing test is notoriously subjective and susceptible to manipulation.

As a result of these problems of overinclusion and indeterminacy, almost wherever functional definitions of financial activities are employed, the definitions also include (either directly or through judicial and administrative interpretations) a series of exceptions and exclusions to prevent confusion and overbroad applications. ${ }^{131}$

\section{Solutions to Overinclusion and Indeterminacy}

There are four basic ways in which courts and legislative drafters impose limitations on functional definitions of financial activities: de minimus exceptions, sophisticated investor exclusions, institutional carve-outs, and extraterritorial exemptions.

\section{a. De Minimus Exceptions}

Many definitions of banking include de minimus exceptions for entities that potentially fall within the scope of a definition but do not engage in sufficiently substantial activities to warrant the exertion of regulatory supervision. De minimus exceptions are implicit in threshold business of banking tests in that they typically specify that, to qualify as the conduct of the business of banking, an entity must engage in core banking functions. ${ }^{132}$ The conduct of incidental or secondary banking activities, being de minimus, will not trigger most threshold business of banking tests. ${ }^{133}$

Similarly, the statutory definition of bank written into the current version

131. For other illustrations of problems in the application of functional definitions, see supra note 19 (ambiguities in definition of employee benefit plan under ERISA) and infra note 137 (difficulties in applying SEC definitions of broker and dealer).

132. See supra note 126.

133. The following excerpt from a Corpus Juris Secondum entry on banks and banking makes precisely this point:

Basically, the business of "banking" consists of accepting deposits, cashing checks, discounting commercial paper, and making loans of money. There are three functions considered to constitute the core of the banking business: accepting deposits, lending, and cashing checks.

That a corporation has been given and exercises certain powers which banks may exercise does not necessarily constitute engaging in banking. Thus, a company is not engaged in banking merely because obtaining, negotiating, and guaranteeing mortgage or other loans, nor is discounting and collecting accounts and commercial paper exclusively a banking business; and one who merely borrows money, giving notes therefor and paying interest, is not engaged in banking. The lending of money from its own assets by a private corporation which has no depositors does not constitute banking business.

9 C.J.S. BANKS AND BANKING $§ 2$ (1996) (footnotes omitted). 
of the Bank Holding Company Act first encompasses a broad range of institutions, but then provides a series of de minimus exemptions for entities whose banking activities are limited to noncommercial or nontransactional services, including certain qualifying trust companies and industrial banks. ${ }^{134}$ De minimus exceptions are also common elsewhere in the field of financial regulation. In a sense, the decision of most insurance commissions not to exert authority over commercial firms offering standard warranties is an example of this tendency. ${ }^{135}$ More common, however, are numerical exclusions. If an investment pool has fewer than one hundred investors, it is exempted from regulation under the 1940 Act under the "private investment company" exemption. ${ }^{136}$ Similarly, securities authorities typically exclude from regulation under the broker-dealer statutes individuals who participate in only a small number of transactions, usually fewer than a handful a year. ${ }^{137}$

De minimus exceptions reflect a sensible balancing of the costs and benefits of regulation. Beneath a certain level of activity, the costs associated with regulatory compliance are just not worth the candle. De minimus exceptions are, however, also susceptible to abuse and manipulation. There is considerable incentive for private parties to avoid regulation by keeping their activities beneath the de minimus level. ${ }^{138}$ Often, what emerges is a series of parallel de minimus exceptions, which if aggregated would cross jurisdictional lines. As a result, regulatory officials must expend some effort policing for abuses of these exceptions. Typically, de minimus exceptions are bounded by functional rules of integration used to determine when formally distinct de minimus activities should be aggregated into a unitary, fullyregulated structure. ${ }^{139}$

134. See Bank Holding Company Act, 12 U.S.C. $\S 1841(c)(2)(D),(H)$ (1994).

135. See supra text accompanying note 129.

136. See Investment Company Act § 3(c)(1), 15 U.S.C. § 80a-3(c)(1) (1994 \& Supp. III 1997).

137. See Vi Louis Loss \& Joel Seligman, SeCurities Regulation 2976-80 \& nn.27-28 (3d ed. 1990) (describing doctrine underlying definitions of broker and dealer under 1934 Act). In a similar spirit is Investment Advisers Act of 1940 §222(d), 15 U.S.C. $§ 80 \mathrm{~b}-18 \mathrm{a}$ (d) (1998), which exempts investment advisers registered in one state from complying with licensing requirements in other states where the adviser has less than six clients.

138. Hedge funds, for example, were originally all designed to fall within the private investment company exception. See Scott J. Lederman, Securities Regulation of Domestic Hedge Funds, in NUTS

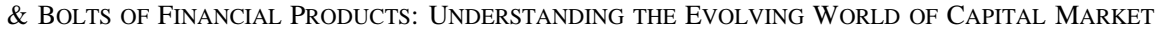
And InVestment Management Products 1998, at 551 (PLI Corp. Law \& Practice Course Handbook Series No. B4-7233, 1998).

139. The SEC's rules for integration of securities offerings under the 1933 Act are a good example of this phenomenon. See, e.g., Securities Act of 1933 Rule 147, 17 C.F.R. $§ 230.147$ (1998) (Preliminary Note 3 ). 


\section{b. Sophisticated Investor Exclusions}

A related, but distinctive limitation on functional definitions is the sophisticated investor exclusion. Under this exclusion, an entity is exempt from some sort of regulatory structure provided the entity limits business activities to transactions with counter-parties who satisfy some minimum standard of expertise or wealth. The classic illustration of such an exemption is the private placement exemption under the Securities Act of $1933^{140}$ and its regulatory extensions, Regulation $\mathrm{D}^{141}$ and Rule 144A. ${ }^{142}$ In 1996 the Investment Company Act of 1940 was amended to allow an analogous exception for investment pools that limit themselves to "qualified purchasers," defined to include individuals with more than five million dollars of investments. ${ }^{143}$

The fact that sophisticated investor exclusions are more commonly found in the securities field has a certain logic. In the area of securities transactions and, to a lesser degree, pooled investment vehicles, the primary impetus for regulatory intervention is to resolve collective action problems of dispersed investors; the primary mechanism of regulatory control is mandatory disclosure and antifraud rules. Once an entity limits itself to sophisticated customers, the collective action problems are less acute, and so our securities laws grant various exemptions, most of which relate to mandatory disclosure obligations but not to antifraud rules. Sophisticated investors, presumably, can decide exactly what information they require and know enough not to make an investment if the disclosure they receive is inadequate. ${ }^{144}$

Sophisticated investor exclusions are less common where the regulatory

140. 15 U.S.C. $\$ 77 d(2)$ (1994).

141. Regulation D-Rules Governing the Limited Offer and Sale of Securities Without Registration Under the Securities Act of 1933, 17 C.F.R. $\$ \S 230.501-230.508$ (1998). Regulation D defines accredited investors to be, among other things, individuals with a net worth of more than one million dollars. See 17 C.F.R. $\$ 230.501$ (a)(5). In a way, Regulation D combines the sophisticated investor exclusion with a de minimus exception by allowing transactions involving up to 35 nonaccredited investors. See id. at $\$ \S 230.501-230.508$; id. at $\$ \S 230.505(a)(2)(i i), 230.506(\mathrm{~b})(2)(\mathrm{i})$ (placing limitation of not more than 35 investors). The regulation does, however, require that such investors receive certain kinds of disclosures and, in certain instances, receive expert assistance. See, e.g., id. at $\S 230.502$ (b) (describing disclosures).

142. Securities Act of 1933 Rule 144A, 17 C.F.R. $\S 230.144$ A (1998) (defining qualified institution buyers generally to encompass institutional investors with more than $\$ 100$ million of investments in unaffiliated securities).

143. See Investment Company Act of 1940, 15 U.S.C. $\S \S 80 a-2(a)(51), 80 a-3(c)(7)$ (1994 \& Supp. III 1997), discussed in JACKSON \& SYMONS, supra note 1, at 845.

144. A similar logic underlay the government's original understanding of the Treasury Amendment of the Commodities Exchange Act, but the Supreme Court declined to accept this interpretation of the relevant statutory language in Dunn v. CFTC, 519 U.S. 465 (1997), discussed in JACKSON \& SYMONS, supra note 1, at 1023-32. 
structures involve more complex intermediaries, such as depository institutions and insurance companies. Again, this tendency conforms with the regulatory justifications for these other fields discussed earlier. Regulation in both of these areas is not solely designed to align informational disparities between investors and intermediaries. The control of externalities and the enforcement of both redistributive norms and considerations of policy economy are reflected in these regulatory regimes. Accordingly, where one does observe sophisticated investor exclusions in these fields-such as the Bank Holding Company Act's exclusion for credit card banks ${ }^{145}$ or the proposed exemption for wholesale financial institutions in recent financial modernization legislation ${ }^{146}$ - the exclusions tend to be partial. Numerous depository institutions and insurance firms limit themselves to transactions with sophisticated customers in the ordinary course of their business but are still subject to a full panoply of regulatory restrictions. ${ }^{147}$

\section{c. Institutional Carveouts}

A third exemption from functional definitions I term an "institutional carveout." This exemption might be thought of as the already-regulatedelsewhere exclusion. Such exclusions are commonly built into functional definitions in recognition that it would be redundant and costly to impose a second system of regulation on an institution that is already subject to a comprehensive system of regulations.

Perhaps the best known example of this approach is the exclusion of banks from the 1934 Act definition of broker-dealer. ${ }^{148}$ This exclusion gained

145. See Bank Holding Company Act of 1956, 12 U.S.C. $§ 1841(c)(2)(F)$ (1994) (exempting from definition of banks credit card institutions that, among other things, do not accept deposits of less than $\$ 100,000)$

146. See H.R. 10, 105th Cong. $§ 136$ (1998) (H.R. 10 as reported out of the Senate Banking Committee on September 21, 1998 as described in S. REP. No. 105-336 (1998)). This proposed legislation would establish a new and hybrid regulatory structure for depository institutions that accept more than a de minimus amount of initial deposits of less than $\$ 100,000$.

147. It is interesting to reflect upon the recent difficulties of some hedge funds in light of the foregoing analysis. See Basel Panel Recommends Limits on Dealings with High-Risk Firms, WALL ST. J., Jan. 29, 1999, at B5. To the extent that the hedge fund exemptions for the 1940 Act were premised on a notion that their failure would impose no substantial externalities on third parties, the controversy over, and regulatory intervention as a result of, the difficulties of the Long-Term Credit Management in Fall 1998 suggests that perhaps some reconsideration of the scope of these exemptions may be in order.

148. "The term 'broker' means any person engaged in the business of effecting transactions for the account of others, but does not include a bank." Securities Exchange Act of $1934 \S 3(\mathrm{a})(4), 15$ U.S.C. § 78c(a)(4) (1994); see also 15 U.S.C. § 78c(a)(5) (1994) (identical exclusion for banks in definition of dealer). The 1940 Act contains an analogous institutional carveout for both banks and bank holding companies. See Investment Advisers Act of 1940 § 202(a)(11), 15 U.S.C. § 80b-2(a)(11) (1994). Although I do not discuss this exemption in the text, it has also been the subject of debate and 
prominence in the 1980s when the D.C. Circuit rebuffed the SEC's attempt to bring bank brokerage activities within the Commission's jurisdiction by adopting new regulations redefining "brokers" and "dealers" for purposes of the 1934 Act. ${ }^{149}$ Ever since that date, the Commission has been attempting to persuade Congress to revise this ruling by amending the 1934 Act's definitions of broker and dealer to provide for a substantially smaller institutional carveout for banks. ${ }^{150}$

Other illustrations of institutional exclusions abound. The 1940 Act, with its broad functional definition of investment pools, excludes from its coverage insurance companies, depository institutions, and pension plans. ${ }^{151}$ Another institutional exclusion can be found in ERISA. In connection with its broad functional definition of regulated plan fiduciaries described above, ERISA provides a series of institutional exemptions for plan assets that are placed under the control of regulated entities. Thus, for example, if plan assets are placed in an investment pool regulated under the 1940 Act, the investment company in control of those assets is expressly excluded from ERISA's definition of plan fiduciary. ${ }^{152}$ A more limited, but structurally similar exemption is available for certain kinds of plan investment assets invested in regulated insurance companies. ${ }^{153}$

The law of depository institutions also makes use of institutional carevouts. So, for example, the Bank Holding Company Act exempts from its definition of bank both thrift institutions and credit unions, two forms of depository institutions that are separately regulated. ${ }^{154}$ State unauthorized banking statutes often have similar institutional carveouts: they cast a broad regulatory net with a functional threshold business of banking test and then provide exemptions for depository institutions subject to other forms of regulation. ${ }^{155}$

\footnotetext{
proposed reform in recent financial modernization legislation.

149. See American Bankers Ass'n v. SEC, 804 F.2d 739 (D.C. Cir. 1986), discussed in JACKSON \& SYMONS, supra note 1, at 1045-56.

150. See, e.g., H.R. 10, 105th Cong. $\S \S 201,202$ (illustrations of proposed legislative language to change current definitions).

151. See Investment Company Act of $1940 \$ \S 3(\mathrm{c})(3),(\mathrm{c})(11), 15$ U.S.C. $\$ 80 a-3(c)(3) \& 3(\mathrm{c})(11)$ (1999), discussed in JACKSON \& SYMONS, supra note 1, at 980-84, 999-1004

152. See ERISA $\S 3(21)(B), 29$ U.S.C. $\S 1002(21)(B)(1994)$.

153. See id. $\S 401(\mathrm{~b})(1)$.

154. See Bank Holding Company Act, 12 U.S.C. $§ 1841(c)(2)$ (1994).

155. See, e.g., IOWA CODE ANN. §524.107(1) (West 1993) ("No person may lawfully engage in this state in the business of receiving money for deposit, transact the business of banking, or may lawfully establish in this state a place of business for such purpose, except a state bank which is subject to the provisions of this chapter, a private bank . . . and a national bank authorized by the laws of the United States to engage in the business of receiving money for deposit.").
} 
The merits of institutional exclusions are self-evident. Once an entity is already subject to one set of regulations, it is costly and wasteful to require the firm to comply with another set of rules and accept oversight from another group of supervisory authorities. To the extent that the justifications for regulatory intervention across sectors of the financial services industry are congruent, one set of regulatory safeguards is an appropriate substitute for another regime. In addition, where institutional carveouts are not available, there are often substantial administrative difficulties present when a single legal entity is required to comply with two competing sets of requirements. For example, the current SEC net-capital requirements for broker-dealers, if applied without adjustment to commercial banks, would impose prohibitively high capital requirements on commercial loans, which lack readily verifiable market values. ${ }^{156}$ Similar conflicts exist when entities must comply with both insurance underwriting and depository institution regulations. ${ }^{157}$

The drawbacks of institutional carveouts are more subtle. The chief problem with institutional exclusions is that the regulatory goals and strategies of the regulation governing the excluded institution may differ in important respects from the goals and strategies of the regime that acquiesces as a result of the exclusion. To make this point more concrete, consider the regulatory strategies of broker-dealer regulation in the United States: heavy emphasis on fiduciary duties, considerable scrutiny on individual qualifications, and lots of disclosure obligations. In granting an exclusion for banks from the definition of broker-dealers, the 1934 Act acquiesces to a regulatory regime that proceeds on quite different operating principles: mostly portfolio-shaping rules and mandatory bonding arrangements, most of which offer little protection for investors who rely on banks for assistance with securities transactions. ${ }^{158}$

Similar problems confound the institutional exclusions written into the

156. See JACKSON \& SYMONS, supra note 1, at 739-46 (comparing bank and broker-dealer capital requirements). Another commonly noted conflict is between the federal securities laws' emphasis on disclosure (to facilitate the decisions of investors) and the predilection of bank regulators to keep certain matters confidential (to reduce the risk of systemic runs).

157. See Citicorp v. Board of Governors, 936 F.2d 66 (2d Cir. 1991) (describing efforts of Delaware regulatory framework to deal with conflicts by requiring state banks to isolate insurance activities in separate divisions), discussed in JACKSON \& SYMONS, supra note 1, at 294-302.

158. As a result, federal banking officials have made great efforts to expand their supervisory arsenal to include regulatory tools more analogous to traditional broker-dealer regulation. See, e.g., Interagency Statement on Retail Sales of Nondeposit Investment Products, 1 Fed. Reserve Reg. Serv. 3-1579.51 (Transmittal 177, Nov. 1995), discussed in JACKSON \& SYMONS, supra note 1, at 1054. While such actions correct an important shortcoming of the institutional exclusion, they also create precisely the duplicative regulatory structure the exclusion was designed to prevent. 
1940 Act. The regulatory strategies employed in the 1940 Act-that is, disclosure, fiduciary duties, and portfolio-shaping rules intended, for the most part, to simplify capital structures - are designed primarily to facilitate investor choice. In contrast, depository-institution and insurance-company regulation proceed on more paternalistic premises and depend much less on decision making of public claimants. While there is considerable logic to a paternalistic regulatory structure when public claims are in the form of deposits or insurance policies, the tools do not work nearly as well when the public holds pro rata shares of investment pools. Because of this regulatory mismatch, the SEC has been particularly sensitive when depository institutions and insurance companies have attempted to exploit their institutional exclusions to offer their customers investment pools without being fully subject to 1940 Act regulation. ${ }^{159}$

A final problem with institutional exclusions is the possibility of either opportunistic exploitation or uncertain application. A recent example of this phenomenon involved ERISA's institutional exclusion for certain insurance contracts. The John Hancock Mutual Life Insurance Company apparently relied on this exclusion in offering a product to a ERISA regulated pension plan. Then, when the product did not perform as well as the plan trustee would have liked, the company was sued for violating ERISA's relatively strict fiduciary rules, which, unlike traditional insurance company regulation, allow for private rights of action. The Supreme Court held that the product did not in fact qualify for the institutional exclusion. ${ }^{160}$ Ultimately, Congress intervened to amend the statute and limit the effect of the Court's holding, but the litigation reveals the potential problem with institutional carveouts.

In an analogous dispute several decades earlier, a number of insurance companies developed variable insurance products without complying with federal securities laws in reliance on institutional carveouts for insurance companies in both the Securities Act of 1933 and the Investment Company Act of 1940. The companies subsequently found themselves subject to enforcement actions of the SEC, which eventually persuaded the courts that the relevant institutional carveouts should not be interpreted to cover the

159. These efforts typically end up in litigation brought if not by the SEC then by investment company trade groups. In practice, the courts have been reluctant to endorse aggressive exploitation of the institutional exclusions. See JACKSON \& SYMONS, supra note 1, at 972-84 (discussing lines of authority). And, over the years, intermediaries have learned how to enter new sectors without relying on institutional exclusions. See, e.g., Nationsbank of North Carolina v. Variable Annuity Life Ins. Co., 513 U.S. 251 (1995) (national bank sales of variable annuities), discussed in JACKSON \& SYMONS, supra note 1, at 1126-32; Investment Co. Inst. v. Conover, 790 F.2d 925 (D.C. Cir. 1986) (judicial endorsement of bank efforts to underwrite IRA funds registered under the federal securities laws).

160. See John Hancock Mutual Life Ins. Co. v. Harris Trust \& Sav. Bank, 510 U.S. 86 (1993). 
products in question. ${ }^{161}$

\section{d. Extraterritorial Exemptions}

A fourth and similarly spirited exception is for financial intermediaries, including banking organizations, chartered and primarily conducting operations in foreign jurisdictions. Many definitional statutes include exemptions for banking organizations chartered under foreign laws or for special purpose entities principally organized to do business in foreign markets. Again, the Bank Holding Company Act is illustrative. Foreign banks and organizations that do not do business in the United States except as an incident to activities conducted outside of the United States are expressly exempted from the Act's definition of a bank. ${ }^{162}$ I would also characterize the various accommodations that courts have made to allow for nationwide banking activities at a time when our laws formally prohibited interstate branching as judicially-developed extraterritorial exemptions. ${ }^{163}$

Other interesting illustrations of extraterritorial exemptions involve transactions by U.S. citizens or residents who enter into economic relations outside of our borders, either by traveling to foreign locations or employing agents in remote locations. ${ }^{164}$ Comparable problems arise when foreign entities use domestic agents to reach U.S. customers ${ }^{165}$ and when foreign nationals with pre-existing relationships with foreign intermediaries move into the United States. ${ }^{166}$ And, of course, the emergence of electronic

161. See SEC v. Variable Annuity Life Ins. Co., 359 U.S. 65 (1959) (Securities Act of 1933); Prudential Ins. Co. v. SEC, 326 F.2d 383 (3d Cir. 1964), discussed in JACKSON \& SYMONS, supra note 1 , at $972-85$.

162. See Bank Holding Company Act, 12 U.S.C. $\$ 1841(c)(2)(A),(C)$ (1994).

163. The accommodations allowed national banks to engage in activities other than "general" banking business where branches were not authorized, see, e.g., Clarke v. Securities Indus. Ass'n, 479 U.S. 388, 406 (1987), discussed in JACKSON \& SYMONS, supra note 1, at 1054, and also let out-ofstate banks engage in in-state operations (usually with the help of local intermediaries) without having to submit to local regulatory supervision, see, e.g., State ex rel. Huston v. Shearson/American Express, Inc., 408 N.W.2d 363 (Iowa 1987) (ruling that there was not unauthorized business of banking in Iowa when brokerage firm doing business in that state served as agent for transferring funds to national bank located out of state). See also supra note 137 (discussing extraterritorial exemption for out-of-state investment advisers).

164. See generally Securities Act of 1933 Regulation S, 17 C.F.R. $\S \S 230.901-230.904$ (1998) (defining application of Securities Act of 1933 to offshore offerings).

165. See, e.g., Securities Exchange Act of 1934 Rule 15a-6, 17 C.F.R. § $240.15 a-6$ (1998) (exemption from 1934 Act's broker-dealer registration requirements for certain foreign broker-dealers with limited contacts with United States).

166. See Securities Exchange Act of 1934 Rule 12g3-2, 17 C.F.R. § 240.12g3-2 (1998) (exemptions for 1934 Act's reporting requirements for foreign issuers with limited U.S. resident shareholders); see also Goodwin, Proctor \& Hoar, SEC No-Action Letter, available in 1997 WL 86002 (Feb. 28, 1997) (discussing rules for determining application of federal securities laws to 
commerce over the Internet raises analogous questions regarding the application of U.S. regulatory structures when U.S. residents access Internet sites located in other jurisdictions. ${ }^{167}$

Like other limitations on functional definitions of financial activities, extraterritorial exclusions present conflicting considerations. Exercising jurisdiction over foreign transactions is costly and difficult; moreover, in many jurisdictions it will be redundant if foreign regulatory structures also govern the transactions and are effectively enforced. ${ }^{168}$ On the other hand, open-ended extraterritorial exclusions invite manipulation and potentially undermine domestic regulatory goals. ${ }^{169}$ Without some attention to policing extraterritorial exclusions, a domestic regulatory structure can become eviscerated.

\section{B. A Matrix of Interindustry Competition}

In an effort to summarize a number of the jurisdictional disputes discussed in the preceding sections, I have assembled a Matrix of Interindustry Competition, which is presented in Table II. The vertical axis of the matrix represents the continuum of financial arrangements outlined in Part I, ranging from simple contracts to contingent obligation intermediaries. On the horizontal axis are the regulatory regimes commonly associated with each category of financial arrangement, as described in Part III. Thus, the shaded diagonal line running from the upper left corner of the matrix to the lower right represents the presumptive regulatory regime for each type of financial arrangement: contract law for simple contracts, securities regulation for contracts with multiple counterparties, etc. In most instances, there is a one-to-one relationship between the financial arrangements and the presumptive regimes. Contingent obligations are the exception, at least in the United States, because we have two competing regimes, one for standard insurance companies and the other for ERISA-regulated benefit plans. ${ }^{170}$

\footnotetext{
foreign investment company with U.S. shareholders).

167. See SEC Issues Guidelines for Web Site Creators Offering Securities, WALL. ST. J., Mar. 25, 1998.

168. For a more complete discussion of these tradeoffs, see Howell E. Jackson, Selective Incorporation of Foreign Legal Systems to Promote Nepal as an International Financial Services Centre, in REgulation AND DeREgulation: POlicy AND PRACTICE IN THE Utilities AND FINANCIAL SERVICES INDUSTRY 367 (Christopher McCrudden ed., 1999).

169. Arguably, one example of this phenomenon is regulatory loopholes in U.S. insurance laws that allow Bermuda-based insurance companies to provide insurance for certain U.S. markets without complying with domestic insurance regulations. See Karen H. Kim, Alternative Insurance in the United States and Bermuda and the Threat to Traditional Regulatory Schemes (May 1, 1995) (unpublished manuscript on file with author).

170. See supra notes 101-02 and accompanying text (discussing special rules governing ERISA
} 
If life were simple, each financial arrangement would exist exclusively within its presumptive regulatory regime. In practice, however, many financial activities in the United States over the past twenty years have taken place outside of their presumptive regulatory regimes. Table II illustrates this phenomenon. On the matrix, I have chartered a number of the jurisdictional disputes described earlier in this Essay. Each entry includes a cross reference to a footnote where the dispute is described in greater detail. In each case, I have entered the disputed activity in the row corresponding to the financial arrangement with which the activity is most closely associated and in the column representing the regulatory regime under which at least one party was seeking to have the activity classified. So, for example, the dispute regarding the SEC's jurisdiction over bank brokerage activities, which gave rise to American Bankers Association v. SEC, ${ }^{171}$ is placed in the row for contracts with multiple counterparties (because the dispute involved securities) and the column for depository institution regimes (because the banks were trying to keep the activity within the realm of bank regulation).

At the risk of confusing an already complicated diagram, let me also explain the typeface conventions I have used for each of the entries in Table II. For entries representing the proposed regulatory placement of the party initiating the activity or transaction, I have used either roman or bold typeface. So, for example, in SEC v. Variable Annuity Life Insurance Co., ${ }^{172}$ where insurance companies attempted to establish variable annuities regulated exclusively under insurance law, there is a bold-face entry in the row for pooled investment vehicles and the column for standard insurance law. For entries representing the jurisdictional choice of a disgruntled counterparty after a transaction has taken place, I have used italics. Thus, for cases such as Banco Espanol de Credito v. Security Pacific National Bank, ${ }^{173}$ where plaintiffs attempted to characterize a loan participation as the sale of securities, I have made an italics entry in the row for simple contracts and the column for securities regulation. These typeface conventions will, I hope, help illuminate four observations about the material presented in the matrix.

\section{Migration to Lower Cost Regulatory Environments}

My first and least surprising observation is that initiating parties routinely exploit definitional ambiguity to recharacterize financial activities so that the

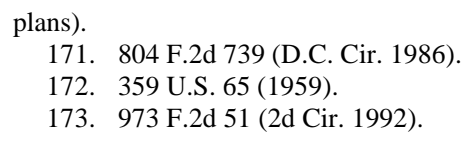


activity will be subject to a regulatory regime that is less costly than the activity's presumptive regulatory regime. In Part III, I argued that regulatory regimes become more costly and onerous as one moves from contract law to more complex intermediary regimes (with the exception of pension law, which is in many respects less costly than standard insurance regulation and even the regulatory structure applicable to depository institutions). These increased costs stem from the fact that these more complex financial arrangements both present greater potential risks, to investors and to third parties, and are subject to more extensive distributive norms and greater considerations of political economy. ${ }^{174}$ The result requires more elaborate supervisory structures and higher regulatory costs. As a result, less costly regimes are generally to the left of an activity's presumptive regime in the Table.

Table II offers strong support for this first observation. If one focuses on the entries in roman typeface - that is, those that represent choices by initiating parties-it is clear that a relatively large number of disputes are in the southeastern quadrant of the matrix. Indeed, the most populated column is the one for contract law. For every kind of financial arrangement discussed, some initiating party has attempted to recharacterize that activity as a largely unregulated contractual undertaking. Conversely, if one looks down the row for simple contracts, one sees no instances in which initiating parties have attempted to recharacterize the activity as one that should be more heavily regulated. (The italicized Banco Espanol and Dunn cases represent after-the-fact litigation by a disgruntled counterparty and the CFTC, respectively.)

Outside of the contract illustrations, one can see in Table II several instances in which instigating parties have attempted to move financial arrangements from more to less heavily regulated environments. The money market mutual funds at issue in the Oregon Attorney General's Opinion, for example, represent an effort on the part of investment companies to provide deposit-like investments in a less costly 1940 Act environment. Bank efforts to offer debt cancellation contracts, retirement CDs, and various other insurance substitutes constitute an analogous effort to move contingent

174. See supra Part III. Table II includes one entry initiated not by a market participant, but by a legal academic. Professor Henry T.C. Hu speculated that investments in a pool of firms with unhedged holdings of gold or gold reserve could constitute a substitute for more traditional (that is, CTFC regulated) means of speculating in gold prices. See Henry T.C. Hu, Hedging Expectations: "Derivative Reality" and the Law and Finance of the Corporate Objective, 73 TEX. L. REV. 985 (1995). Subsequently, the American Stock Exchange implemented Professor Hu's idea with the creation of the "HUI" index option. See Anne Schwimmer, Amex Will Woo Gold Bugs with New Index Product, INVESTMENT DEALERS’ DiG., Mar. 25, 1996, at 3. 


\begin{tabular}{|c|c|c|c|c|c|c|c|}
\hline \multicolumn{8}{|c|}{$\begin{array}{c}\text { Table II } \\
\text { A Matrix of Inter-Industry Competition }\end{array}$} \\
\hline & \begin{tabular}{|l} 
Contract \\
Law
\end{tabular} & \begin{tabular}{|l|} 
Securities \\
Regulation
\end{tabular} & \begin{tabular}{|l|} 
CTFC \\
Regulation
\end{tabular} & $\begin{array}{l}1940 \\
\text { Act }\end{array}$ & \begin{tabular}{|l|} 
Depository \\
Institution \\
Regimes \\
\end{tabular} & $\begin{array}{l}\text { Standard } \\
\text { Insurance } \\
\text { Laws } \\
\end{array}$ & ERISA \\
\hline $\begin{array}{l}\text { Simple } \\
\text { Contract }\end{array}$ & $\begin{array}{l}\text { Presumptive } \\
\text { Regulatory } \\
\text { Regime }\end{array}$ & \begin{tabular}{|l} 
Banco \\
Espanol de \\
Credito (n.6)
\end{tabular} & $\begin{array}{l}\text { Dunn v. } \\
\text { CFTC } \\
\text { (n.12) }\end{array}$ & & & & \\
\hline $\begin{array}{l}\text { Contracts } \\
\text { With } \\
\text { Multiple } \\
\text { Parties } \\
\end{array}$ & $\begin{array}{l}\text { W.J. Howey } \\
\text { (n.5) }\end{array}$ & $\begin{array}{l}\text { Presumptive } \\
\text { Regulatory } \\
\text { Regime }\end{array}$ & & & $\begin{array}{l}\text { ABA v. SEC } \\
\text { (Rule 3b-9) } \\
\text { (n.149) }\end{array}$ & & \\
\hline $\begin{array}{l}\text { Contracts } \\
\text { With } \\
\text { Duration }\end{array}$ & $\begin{array}{l}\text { Swaps } \\
\text { Market; } \\
\text { Offshore } \\
\text { Internet } \\
\text { (nn.112, 167) }\end{array}$ & $\begin{array}{l}\text { Chicago } \\
\text { Mercantile }^{*} \\
\text { \& Bankers } \\
\text { Trust Swaps } \\
\text { Cases (n.12) }\end{array}$ & $\begin{array}{l}\text { Presumptive } \\
\text { Regulatory } \\
\text { Regime }\end{array}$ & $\begin{array}{l}\text { Prof. Hu's } \\
\text { Gold Pool } \\
\text { (n.174) }\end{array}$ & & & \\
\hline $\begin{array}{l}\text { Pooled } \\
\text { Investment } \\
\text { Vehicles } \\
\end{array}$ & $\begin{array}{l}\text { Bank Trust } \\
\text { Activities } \\
\text { (n.54) }\end{array}$ & $\begin{array}{l}\text { Hedge } \\
\text { Funds } \\
\text { (n.138) }\end{array}$ & $\begin{array}{l}\text { Chicago } \\
\text { Mercantile } \\
\text { Case }^{*} \text { (n.12) } \\
\end{array}$ & $\begin{array}{l}\text { Presumptive } \\
\text { Regulatory } \\
\text { Regime }\end{array}$ & $\begin{array}{l}\text { Market- } \\
\text { Index CD } \\
\text { (n.176) }\end{array}$ & $\begin{array}{l}\text { SEC v. } \\
\text { VALIC } \\
\text { (n.120) }\end{array}$ & $\begin{array}{l}\mathbf{4 0 1}(\mathrm{k}) \\
\text { Pension } \\
(\mathrm{n} .178)\end{array}$ \\
\hline $\begin{array}{l}\text { Fixed } \\
\text { Obligation } \\
\text { Intermediaries }\end{array}$ & \begin{tabular}{|l} 
Texas Att'y \\
Gen. Op. \\
(e-card); \\
(n.126)
\end{tabular} & $\begin{array}{l}\text { Gary } \\
\text { Plastic Case } \\
\text { (n.6) }\end{array}$ & & $\begin{array}{l}\text { Oregon } \\
\text { Att'y Gen. } \\
\text { Op. } \\
\text { (MMF) } \\
\text { (n.16) }\end{array}$ & $\begin{array}{l}\text { Presumptive } \\
\text { Regulatory } \\
\text { Regime }\end{array}$ & \begin{tabular}{|l|} 
Texas \\
Commerce \\
(GIC's) \\
(n.177)
\end{tabular} & \\
\hline $\begin{array}{l}\text { Contingent } \\
\text { Obligation } \\
\text { Intermediaries }\end{array}$ & \begin{tabular}{|l} 
Warranty \\
Cases \& \\
Bermuda \\
Insurance \\
(nn.129, 167)
\end{tabular} & $\begin{array}{l}\text { Daniels; } \\
\text { \& Viatical } \\
\text { Agreements } \\
\text { Cases } \\
(\mathrm{nn} .184,185)\end{array}$ & & & $\begin{array}{l}\text { Taylor \& } \\
\text { Schacht } \\
\text { Cases (bank } \\
\text { insurance } \\
\text { substitutes) } \\
\text { (nn.18, 201) }\end{array}$ & $\begin{array}{l}\text { Presumptive } \\
\text { Regulatory } \\
\text { Regime }\end{array}$ & $\begin{array}{l}\text { Self-Insured } \\
\text { ERISA } \\
\text { Plans; John } \\
\text { Hancock } \\
\text { Case } \\
\text { (nn.51, 101) }\end{array}$ \\
\hline
\end{tabular}

obligations into a depository institution regime. In a similar vein, private investment companies are a means of offering investment pools under federal securities law regimes, but without the added complexity of the 1940 Act. I would also describe ERISA self-insured plans as reflecting a similar phenomenon because these plans often represent employer efforts to evade costly insurance regulations by coming under the preemptive power of ERISA's alternative structure.

* I locate the Chicago Mercantile case in two boxes because the case presented two opposing perspectives over the regulation of extended duration contracts tied to the future value of a basket of securities. The long position in such a contract is the functional equivalent of an investment in a mutual fund consisting of the relevant basket. The prevailing party argued that the CFTC should have exclusive jurisdiction over this product, thus shifting a pooled investment vehicle from 1940 supervision to CFTC oversight. The other side accepted CTFC jurisdiction but argued the SEC should have concurrent oversight authority, attempting to recharacterize the product as one to appropriate for federal securities regulation. See JACKSON \& SYMONS, supra note 1, at 1008-20. 


\section{Opportunistic Use of Institutional Carveouts}

Another recurring strategy reflected in Table II is the use of institutional carveouts to gain regulatory advantage. The entries in bold represent instances in which initiating parties have attempted to move a financial arrangement into a regulatory regime that generally would be considered more onerous than the arrangement's presumptive regime, but the particular case allowed the initiating party to exploit some sort of institutional carveout. The placement of brokerage activities inside the depository institution structure, which was the impetus for American Bankers Association v. $S E C,{ }^{175}$ would be a prime example of this tactic. That effort allowed banks to enter the discount brokerage business, but without complying with SEC requirements imposed on ordinary broker-dealers. To a similar effect would be efforts on the part of insurance companies to sponsor variable insurance products, a form of pooled investment vehicle, without fully complying with the requirements of the 1940 Act. Attempts of banks to offer certificates of deposit with rates of return contingent upon the performance of stock market indices have a similar characteristic. ${ }^{176}$ Similar too would be efforts of insurance companies to market guaranteed investment contracts ("GICs") in the 1980s as substitutes for more heavily-regulated bank deposits. ${ }^{177}$ Another example would be $401(\mathrm{k})$ and other types of defined contribution pension plans that allow employers to offer their employees pooled investment vehicles for retirement savings. ${ }^{178}$

As a corollary to this observation, I should add that Table II also contains two instances in which initiating parties have arguably exploited foreign exemptions to similar effect. The location of various insurance companies in Bermuda allows certain companies to provide insurance products to some U.S. customers without complying with local insurance regulations. ${ }^{179}$ Similarly, foreign-based Internet sites offering securities products without triggering SEC oversight are engaged in an equivalent strategy of regulatory avoidance. $^{180}$

175. 804 F.2d 739 (D.C. Cir. 1986).

176. See Investment Co. Instit. v. Ludwig, 884 F. Supp. 4 (D.D.C. 1995).

177. See Commercial Nat'l Bank in Shreveport v. Superior Court, 17 Cal. Rptr. 2d 884 (1993), discussed in JACKSON \& SYMONS, supra note 1, at 479-90.

178. For a discussion and critique of this practice, see SECURITIES \& EXCH. COMM'N, PROTECTING INVESTORS: A HALF-CENTURY OF INVESTMENT COMPANY REGULATION ch. 3 (1992).

179. See supra note 169.

180. See supra note 167. 


\section{Ex Post Manipulation by Disgruntled Parties}

My third observation is that disgruntled counterparties also behave opportunistically in this arena. Counterparty efforts to recharacterize activities are represented in italics in Table II. Perhaps not surprisingly, these entries abound in the column associated with securities regulation, where private rights of action constitute a important element of supervisory oversight. In numerous settings, disgruntled counterparties have attempted to recharacterize financial arrangements as securities so as to be able to take advantage of private rights of action available under the federal securities laws. Many definition-of-securities cases (including the Howey ${ }^{181}$ land development case itself) concern contracts that plaintiffs recast as securities. Similarly, in Bankers Trust litigation with Procter and Gamble, plaintiffs argued that swaps and similar derivatives should be treated as securities. ${ }^{182}$ And in a other cases involving bank CDs, ${ }^{183}$ viatical agreements, ${ }^{184}$ and pension plans ${ }^{185}$ plaintiffs have attempted to recast as securities what were originally constituted as deposits, insurance products, and pension plans. Likewise in the John Hancock case, ${ }^{186}$ an ERISA plan trustee argued that an insurance company should be treated as an ERISA trustee, and thus liability for breach of fiduciary duty should arise. ${ }^{187}$ As with the federal securities laws, ERISA creates private rights of action, which formed the basis of the plaintiff's claim in the Hancock case.

\section{Regulatory Complicity in Recharacterizations}

My final observation about the matrix concerns the extent to which regulatory authorities have participated in the recharacterization of financial arrangements described above. This practice is most apparent if one looks down the column for depository institution regimes. In all of the cases illustrated in this column, bank regulatory authorities issued formal pronouncements sanctioning the new activity and often times played crucial roles in defending the recharacterization in court. Insurance regulators played

\footnotetext{
181. SEC v. W.J. Howey Co., 328 U.S. 293 (1946).

182. Proctor \& Gamble Co. v. Bankers Trust Co., 925 F. Supp. 1270 (S.D. Ohio 1996).

183. See, e.g., Gary Plastic Packaging Corp. v. Merrill Lynch, Pierce, Fenner \& Smith, Inc., 903 F.2d. 176 (2d Cir. 1990) (brokered deposits as securities).

184. Viatical agreements involve the sale of life insurance policies, usually to patients with AIDS or some other life-threatening disease. See SEC v. Life Partners, Inc., 102 F.3d 587 (D.C. Cir. 1996).

185. See International Bhd. of Teamsters v. Daniels, 439 U.S. 551 (1979), discussed in JACKSON \& SYMONS, supra note 1 , at 985-93.

186. John Hancock Mut. Life Ins. Co. v. Harris Trust \& Sav. Bank, 510 U.S. 86 (1993).

187. See supra text accompanying note 160 .
} 
a similar role in launching the variable insurance products and GIC's located in the column under standard insurance laws, as did the SEC in the index participation product that gave rise to the Chicago Mercantile case, ${ }^{188}$ which appears in the column under securities regulation.

\section{Concluding Comments}

Taken together, what conclusions should one draw from this matrix? One could, I suppose, simply conclude that the classification of financial products is a difficult undertaking and, as no system of classification will be perfect, disputes over classification are inevitable, albeit unfortunate. While I do not disagree with this statement, I think the value of the matrix is that it illustrates that disputes over classification are not simply random events but rather are the result of several recurring phenomena. As long as we maintain a multisectored system of financial regulation-with comparatively high and low cost areas of regulation-parties will have incentives to relocate activities to less expensive regulatory environments, either through recharacterizing the transactions upfront or by exploiting the institutional carveouts and foreign exemptions that are typically built into definitional provisions. Moreover, as long as our regulatory systems offer private rights of action for some regulatory products and not for others, there will be incentives for disgruntled counterparties to recharacterize products ex post in order to initiate litigation. This phenomenon creates predictable pressure on whatever regulatory classifications are enacted.

My observation about the tendency of regulatory authorities to participate in regulatory reclassifications also has implications for our standard response to difficult questions of administrative law: deference to agency expertise. The Chevron doctrine, ${ }^{189}$ elevating administrative expertise over judicial oversight, is premised on the existence of a disinterested agency attempting in good faith to interpret statutory provisions with whose administration the agency is charged. However valid this assumption is in other contexts, the matrix of interindustry competition raises serious questions about its application where the legal issues involve the jurisdictional boundaries between regulatory fields. Wholly apart from the temptation of jurisdictional hegemony, regulatory agencies are understandably under continuous pressure to allow firms under their supervision to offer new kinds of products, which both increase industry profitability and satisfy consumer demands. Absent

188. Chicago Mercantile Exch. v. SEC, 883 F.2d 537 (7th Cir. 1989).

189. Chevron U.S.A. Inc. v. Natural Resources Defense Council, Inc., 467 U.S. 837 (1984), discussed in JACKSON \& SYMONS, supra note 1, at 64-66. 
clear threats to the solvency of institutions engaging in the activity, there will often be little reason for regulatory authorities to resist proposals to push definitional boundaries of authorized activities. The incentives, therefore, push supervisory agencies towards authorizing new activity. In many cases, the only countervailing consideration is the prospect that the approval may be challenged in court, but even that factor is likely to be discounted as the Chevron doctrine enhances the likelihood of judicial affirmation, provided the authorization has at least superficial plausibility. ${ }^{190}$

Of course, the tendency of regulatory agencies to endorse ever-expanding activities may have certain advantages - it keeps the regulatory structure dynamic, provides consumers new products, and stimulates interindustry competition. For these reasons, one might regard the phenomenon as essentially a positive attribute. In my view, however, there are also less salutary aspects of the tendency. Among other things, regulatory officials are not always sensitive to the supervisory practices and policy concerns of other fields of regulation. For example, under the 1940 Act, the SEC polices money market mutual funds that are functionally equivalent to bank deposits but are neither burdened by the many social obligations imposed on depository institutions nor safeguarded with the same protections against bank runs and other systemic problems. Likewise, bank regulatory agencies authorize bank-based insurance substitutes but then do not subject them to the same restrictions on risk classifications as are imposed on traditional insurance companies nor do they impose policy reserve requirements equivalent to those developed over the years in the insurance industry. Even when regulatory authorities attempt to replicate the regulatory structures imposed in other fields, it is not always clear they have the same expertise and enforcement incentives as the agencies with primary jurisdiction in the area. ${ }^{191}$ At a minimum, the tendency of regulators to support product innovation may force traditional providers into a position of competitive

190. See, e.g., Independent Ins. Agents of America v. Ludwig, 997 F.2d 958 (D.C. Cir. 1993) (judicial endorsement of OCC ruling that arguably lacked superficial plausibility), discussed in JACKSON \& SYMONS, supra note 1, at 1121-26. In the depository institution sector, where firms can organize as either state-chartered or national banks and where even federal authority is divided among several agencies, see supra text accompanying note 34, there is increased pressure for regulatory authorities to be responsive to innovative proposals of regulated entities.

191. See generally Financial Modernization-Part II, Hearings Before the Comm. on Banking and Fin. Servs., 105th Cong. 483 (1997) (testimony of Athur Levitt, Chairman, Securities and Exchange Commission) [hereinafter Levitt Testimony]; see also Concerning H.R. 10, The "Financial Services Act of 1999," Hearings Before the House Comm. on Banking and Fin. Servs., 106th Cong. (Feb. 12, 1999) (testimony of Harvey J. Goldschmid, General Counsel, Securities and Exchange Commission), available in 〈http://www.house.gov/banking/21299sch.htm> [hereinafter Goldschmid Testimony]. 
disadvantage. More troubling, these innovations, if not properly overseen, could potentially undermine important public goals of risk regulation and other social policies.

\section{FUNCTIONAL REGULATION}

In this final Part, I would like to make a few remarks about the recent trend towards functional regulation in the financial services industry. As defined by Secretary of the Treasury Robert Rubin, functional regulation is "a regulatory process in which a given financial function is regulated by the same regulator regardless of who conducts the activity." 192 The concept has a long pedigree in the financial reform literature $;{ }^{193}$ it has numerous supporters in the academic community, including most notably Nobel laureate Robert C. Merton; ${ }^{194}$ and the approach figures prominently into the reform legislation pending before Congress. ${ }^{195}$

The case for functional regulation is both powerful and familiar. The approach creates competitive equality across industry participants, as the same regulations apply regardless which entity offers a product. It improves regulatory efficiency by allowing regulators to specialize in supervising

192. H.R. 1062, The Financial Services Competitiveness Act of 1995, Glass-Steagall Reform and Related Issues (Revised H.R. 18)_Part I: Hearings Before the House Comm. on Banking and Fin. Servs., 104 Cong. 267 (1995).

193. See Melanie L. Fein, Functional Regulation: A Concept for Glass-Steagall Reform?, 2 STAN. J.L. BUS. \& FIN. 89 (1995) (reviewing history of functional regulation; see also Heidi Mandanis Schooner, Regulating Risk Not Function, 66 U. CIN. L. REV. 441 (1998) (exploring elements of functional regulation in our current regulatory structure and advocating as a basis for future reforms a regulatory division based on risk).

194. See Robert C. Merton, A Functional Perspective of Financial Intermediation, FInANCIAL MANAgement, Summer 1995, at 23; see also Robert C. Merton \& Zvi Bodie, A Conceptual Framework for Analyzing the Financial Environment, in Dwight B. CRANE ET AL., The Global FinANCIAL SySTEM: A FunCTIONAL PERSPECTIVE 3 (1995).

The functional distinctions advocated in Professor Merton's writings differ considerably from the ones I use in this Essay, which track the categories commonly employed in public debate over financial reform legislation. From a theoretical perspective, there is much to be said for Professor Merton's approach, which subdivides financial activity into more basic components (clearing \& Settling; pooling; transferring resources; risk management; information; and incentives). And-putting to one side the practical difficulties - one could imagine creating a new system of financial supervision with a unique regulatory framework for each of Professor Merton's basic financial functions. Once such a system was constructed, however, I would predict that many of the phenomenons discussed in this Essay would come into play. Private parties, perhaps with regulatory complicity, would attempt to recharacterize functions to become subject to whatever is perceived to be the lowest cost sector of the system; plausible claims for various kinds of exemptions (de minimus exceptions; sophisticated party exclusions; institutional carve-outs; and extraterritorial exemptions) would arise; and, over time, the purity of the functional structure would be compromised.

195. For example, title III of H.R. 10 as reported out of the Senate Banking Committee includes three subtitles that would have created functional regulation for broker-dealer activities of banks, investment company activities of banks, and the holding companies of investment banks. 
functionally equivalent activities. And, it enhances investor protection by ensuring both that all financial services providers are properly supervised and that the degree of supervision is comparable across sectors of the financial services industry. ${ }^{196}$ There are also reasonably well-known critiques of functional regulation, related primarily to the costs associated with requiring firms to comply with the requirements of multiple regulators and dangers associated with the fact that, under some systems of functional regulation, no single regulatory authority has overall responsibility for an entity's solvency and risk management. ${ }^{197}$ Without reopening the entire debate over functional regulation, I want to conclude this Essay with a series of comments about recent proposals in light of the analysis presented above.

\section{A. Antecedents of Functional Regulation}

An initial point to be made about our current system of financial regulation is that the system already rests on a network of functional definitions. From securities regulation to depository institution law, from the Investment Company Act of 1940 to traditional insurance regulation, every area of financial regulation in the United States depends on some sort of functional definition to determine which firms must comply with which regulatory structure. ${ }^{198}$ As explored above, the principal problem with these functional definitions is that they are overinclusive and indeterminate. Many activities are potentially encompassed in two or more functional definitions, and hence it has proved necessary to develop a series of limiting principlesthat is, de minimus exceptions, sophisticated investor exclusions, institutional carveouts, and extraterritorial exemptions. ${ }^{199}$ Over time, a variety of factors have encouraged the financial services industry to exploit the inherent ambiguity of these functional definitions - and the possibilities of evasion made available by institutional carveouts and various other limitations-to undermine the integrity of the functional definitions upon which our current regulatory structure is based. Returning for a moment to Table II, the Matrix of Interindustry Competition, one might conceptualize the shaded diagonal line of presumptive regulatory regimes as a pure system of functional regulation and every off-diagonal entry on the matrix as an attempt of some party to corrupt that purity.

Viewed in this light, recent proposals to impose functional regulation on

196. See Fein, supra note 193, at 105-08 (reviewing purported benefits of functional regulation).

197. See id. at 109-13 (summarizing critique).

198. See supra Part IV.A.2 (reviewing various kinds of functional definitions).

199. See supra Part IV.A.3 (describe four types of limitations). 
the financial services industry might be better understood as less of a crusade to impose a new regulatory paradigm but rather a more modest effort to reduce the capacity of parties to exploit the ambiguity and limitations made available under current law. A perfect illustration of this understanding are reforms designed to limit the ability of depository institutions to take advantage of an institutional carveout in the 1934 Act's definition of broker and dealer. Currently, the law simply exempts any "bank" from these definitions, but under the various reform proposals, the institutional carveout would be narrowed to exempt only banks that engage in a small number of transactions each year or that engage in a narrowly prescribed set of securities activities that are closely related to traditional banking activities. ${ }^{200}$ Some of these exceptions are applicable only if the bank limits itself to doing business with wealthy customers or institutional investors. In other words, the current open-ended institutional carveout for banks would be replaced by a more finely articulated exemption including, among other things, a tailored institutional carveout, a limited purpose de minimus exemption, and a sophisticated investor exclusion for certain products.

To the extent that functional regulation reform proposals are better understood as refinements of our current regulatory structure, it follows that all of the pressures exerted on our current regulatory system will apply to the reformed system. In particular, as long as the reformed system imposes different kinds of regulatory structures with different compliance costs on various financial products, there will be incentives for parties and regulatory authorities to recharacterize transactions to suit their own needs and interests. Proclaiming our allegiance to functional regulation will do nothing to alleviate these pressures. The real issue is whether the new jurisdictional definitions do a better job of clarifying which financial activities should be regulated in which ways. While reforms such as the proposed revision of the 1934 Act's definition of broker and dealer do seem to move in this direction, even here one needs to withhold judgment until it is clear how the various limitations written into this new provision will be applied in practice.

\section{B. Reallocation of Interpretative Authority}

From my perspective, one of the most intriguing elements of recent

200. See H.R. 10, 105th Cong. § 201 (1998) (H.R. 10 as reported out of the Senate Banking Committee on September 21, 1998 as described in S. REP. NO. 105-336 (1998)), discussed in JACKSON \& SYMONS, supra note 1, at 1054-55. There are, of course, differences as to whether the resulting exemptions are narrow enough. See Goldschmid Testimony, supra note 191 (arguing for narrower exemptions). 
functional regulation reform proposals is not the effort to implement such a regulatory structure but the creativity that has gone into developing new mechanisms to resolve disagreements over classifications. As explained above, our current regulatory system - based as it is on the Chevron doctrine of judicial deference to agency expertise-grants administrative agencies considerable latitude in defining jurisdictional boundaries. As discussed earlier, this approach facilitates the natural, but not necessarily desirable, tendency of regulatory officials to expand the boundaries of their own jurisdiction and the lines of authorized business of each sector of the industry. It also engenders the recurring problem of one financial product being classified in two or more different ways by different regulatory authorities. $^{201}$

Viewed broadly, the debate over financial reform has advanced at least three different ways of resolving this problem. One approach is simply to establish a hierarchy among regulatory interpretations and grant a single agency the power to make binding decisions with respect to financial arrangements arguably within its jurisdiction. That is essentially the approach Congress took in the 1980s when it divided jurisdiction over futures markets between the CFTC and SEC. ${ }^{202}$ At various times, SEC Chairman Arthur Levitt has recommended that his agency should have similar authority to determine whether an activity constituted a securities transaction or the business of banking. ${ }^{203}$ Similarly, state insurance regulators have argued for comparable statutory authority to determine whether a particular activity should be considered insurance as opposed to a banking product. ${ }^{204}$

One of the interesting features of the reform bill reported out of the Senate Banking Committee in September 1998 was its reluctance to pick regulatory sides in the allocation of interpretative authority. Rather, at several crucial junctures, the Committee chose to propose specialized provisions for judicial review under which the courts were instructed to give equal deference to all relevant regulatory authorities. ${ }^{205}$ In other words, for this

201. See SEC v. Variable Annuity Life Ins. Co., 359 U.S. 65 (1959) (variable insurance classified as both insurance and security); NationsBank of N.C. v. Variable Annuity Life Ins. Co., 513 U.S. 251 (1995) (sale of annuity is both banking and insurance); American Deposit Corp. v. Schacht, 84 F.3d 834 (7th Cir. 1996) (retirement CD classified as both insurance and deposit).

202. See Chicago Mercantile Exch. v. SEC, 883 F.2d 537 (7th Cir. 1989), discussed in JACKSON \& SYMONS, supra note 1, at 1008-20.

203. See Levitt Testimony, supra note 191.

204. See H.R. 10 and Financial Modernization, Hearings Before the Senate Comm. on Banking, Housing, and Urban Affairs, 105th Cong. (June 25, 1998) (testimony of George Nichols III, Chairman NAIC Special Committee on Banks and Insurance), available in <http://www.naic.org/1news/ testimonies/62598GN.htm>.

205. See, e.g., H.R. $10 \S 206$ (determining which activities entitled to "traditional banking 
limited category of cases, the Committee would have abandoned the Chevron doctrine and substituted the courts as the authoritative body for resolving certain jurisdictional disputes.

Elsewhere in the reform debate, more collaborative dispute resolution approaches have been proposed. In Spring 1997 when the Treasury Department offered its own blueprint for financial modernization, it recommended the creation of a new National Council for Financial Services, consisting of the Secretary of the Treasury and a collection of federal and state regulators, to resolve disagreements over jurisdictional boundaries. ${ }^{206}$ Such an approach would have relocated interpretative authority from individual agencies and the courts into this council. The legislative reform bill that emerged from the Senate Banking Committee last Fall did not include the Treasury's council, but it did include other illustrations of collaborative decision making. In particular, in articulating the kinds of financial activities permissible for bank holding companies under proposed legislation, the Senate Banking Committee's bill called upon the Federal Reserve Board and the Treasury Department - two federal banking agencies that occasional disagree over interpretative issues-to collaborate in articulating new financial activities. ${ }^{207}$ Under this approach, without the concurrence of both agencies, new financial activities would not be recognized.

It is beyond the scope of this Essay to consider which of these various approaches to the allocation of interpretive authority is the most appropriate for our regulatory system. My point is simply to highlight how important this authority is in a system of functional regulation and to note that there are numerous different ways to construct solutions to this problem.

\section{On Implementing Functional Regulation}

Finally, let me address the deeper question of how Congress, the courts, and the regulatory agencies should decide how particular financial transactions should be classified under a system of functional regulation and, also, how the system itself should be designed. Clearly, this is a large topic worthy of a separate essay, if not longer treatment. But much of analysis

\footnotetext{
product" exception to SEC broker-dealer rules); id § 306 (determining whether certain banking activities constitute insurance).

206. See Financial Modernization-Part II, Hearings Before House Comm. on Banking and Fin. Servs., 105th Cong. 576 (1997) (Testimony of John D. Hawke, Jr., Under Secretary of the Treasury for Domestic Finance). As a matter of full disclosure, I should note that I played a very minor role in helping formulate this proposal as an outside consultant to the Treasury Department.

207. See H.R. $10 \S 103$.
} 
presented above bears on that question, and it seems appropriate to close with a summary of what I believe to be the most salient points.

\section{Greater Attention to Regulatory Justifications}

In my view, one of the weaknesses of much of the debate over functional regulation is the extent to which the debate develops into competing analogies: whether a certain new transaction, for example, is more like insurance or more like securities. While analogies are an important aid in such debates, the more fundamental question is whether the activity in question implicates the policy concerns that led us to develop one system of regulation (say, insurance regulation) or another (such as banking regulation). Even recent reform legislation tends to emphasize product analogy over more fundamental analysis. ${ }^{208}$

One of the claims of this Essay is that policies underlying financial regulation in this country differ across sectors. While every sector presents concerns of investor protection, the intensity of that concern varies from sector to sector. More importantly, the potential for substantial negative externalities differs from sector to sector, as do redistributive norms and relevant considerations of political economy. So, for example, in considering whether a product should be considered a security or a banking product, I believe it would be relevant to consider whether the product creates the potential for externalities (for example, bank runs) typically associated with depository institutions. Should, moreover, the product be governed by the political and social imperatives underlying the Community Reinvestment Act? Does the product present the sort of investment risks that warrant disclosure requirements and antifraud rules associated with federal securities laws? These additional considerations will not, necessarily, decide every case, but they are, in my view, more informative than the question of whether the product looks more like a deposit than a security. ${ }^{209}$

208. For example, describing how courts should determine whether a product is insurance or banking, section 306 of H.R. 10, as reported out of the Senate Banking Committee, proposes consideration of "the nature of the product or activity and the history and purpose of its regulation under State and Federal law." H.R. $10 \S 306$. I suppose one could read the phrase "purpose of its regulation" as an invitation to consider underlying policies, but it is not clear that this phrase has any applicability to a new product that has hitherto not been regulated at all.

209. This approach, to be sure, assumes that our current regulatory structure represents a legitimate manifestation of social norms and political considerations-an assumption that not all readers will share. 


\section{Practical Difficulties of Pure Functional Regulation}

A further point to be made about the design of a working, as opposed to theoretical, system of functional regulation is the recognition that it is not, in fact, always feasible or desirable to regulate two financial products in exactly the same way, even if one concludes that the products are functionally equivalent and implicate precisely the same sort of risk considerations and social or political values. Sometimes, it just will not be worth the effort. Other times it will be impossible to impose multiple regulatory structures on the same legal entity. While recent reform efforts have generally championed functional regulation, they have implicitly accepted these practical limitations in its implementation in the real world. Thus, current reforms embrace what I would characterize as a pragmatic rather than pure system of functional regulation.

\section{a. Cost Considerations}

Sometimes an entity will engage in such a small amount of a financial activity that it is not worth the trouble of making it comply with an additional regulatory structure. This, of course, is the logic underlying de minimus exceptions in the first place, but it seems to me particularly appropriate to structure these exceptions more broadly when the entity in question is already subject to some sort of regulatory oversight. In the area of brokerdealer regulation, recent reform legislation has taken just this approach with respect to banks. Ordinarily, if a firm engages in a dozen or more securities transactions a year, it must register with the SEC and comply with a wide range of regulatory standards. Under the Senate Banking Committee bill of September 1998, banks enjoyed a similarly motivated exemption, except that the number of permissible transactions per year for banks was raised to five hundred. ${ }^{210}$ Several other of the bill's limitations on SEC functional regulation over banks have a similar characteristic: they allow banks an exemption from SEC broker-dealer activity for activities that would bring an ordinary firm under SEC oversight. ${ }^{211}$ Although one might quibble over whether five hundred is too high (or too low) a threshold, the structure of this compromise strikes me as eminently sensible. It makes sense to impose supervision on a private party engaging in a limited amount of securities

210. See H.R. $10 \S 201$.

211. See id. (engaging in transactions in commercial paper); id. (participation in private securities offerings). 
activities before imposing such oversight on a regulated bank. ${ }^{212}$

\section{b. Inconsistencies in Regulatory Strategies}

Another practical difficulty that precludes implementation of an ideal system of functional regulation concerns inconsistencies in regulatory strategies. As explored above, certain regulatory strategies cannot easily be imported across sectors of the financial services industry. The mark-tomarket accounting underlying the SEC's net capital rules for broker-dealers is not a standard that can readily be imposed on entities, such as depository institutions and certain insurance companies, that invest a large portion of their assets in illiquid loans. Similarly, disclosure-based regulatory systems are in tension with regulatory strategies that proceed on the basis of confidentiality and behind-the-scene corrective actions.

To a considerable degree, financial modernization legislation has recognized this reality. Rather than pushing functional regulation to its logical limit, in several areas reform proposals advocate "push-out" strategies, allowing intermediaries to expand across certain jurisdictional boundaries but only if the activities are located in separately organized affiliates or subsidiaries. The Senate Banking Committee bill of Fall 1998 relied on this approach in its provisions allowing banks to enter into the securities underwriting business as well as insurance underwriting. ${ }^{213}$ This approach has antecedents in both the Federal Reserve Board's section 20

212. When the costs of pure functional regulation are too high, another alternative is to rely on various hybrid forms of functional regulation. In a pure system of functional regulation, all equivalent activities are regulated by the same regulatory authority under the same set of substantive rules. It is, however, possible to imagine a system where the lead regulatory promulgates the substantive rules, but other regulators enforce those rules to firms within their jurisdiction. That, in essence, is how government securities activities of banks and certain securities firms are policed. In addition, it is also possible for the local regulators to develop their own set of specialized rules for nontraditional activities and then to apply those rules to firms under their supervision. In the aftermath of the American Bankers Ass'n v. SEC, 804 F.2d 739 (D.C. Cir. 1986), that is how the federal banking agencies have policed the securities activities of banks. For further discussion of these examples and an interesting exploration of other hybrid forms of functional regulation, see Martha L. Cochran \& David F. Freeman, Jr., The Regulatory Environment: Functional Regulation (unpublished manuscript, on file with author).

213. See S. REP. No. 105-336, at 9-10 (1998) (describing "push-out" strategy). A surprising amount of the remaining controversy over financial modernization deals with the relatively narrow question of the precise form of these push-out requirements. The Treasury Department advocates a relatively more liberal application that would allow banks to choose between operating subsidiaries and holding company affiliates, while the Federal Reserve Board prefers push-out strategies that limit many activities to holding company affiliates. Not surprisingly, these perspectives track the two agencies' jurisdictional boundaries. See New Senate Banking Chief Plans To Move Swiftly on Financial-Services Overhaul, WALL ST. J., Jan. 13, 1999, at A4; cf. supra note 190 (discussing incentives of bank regulators to support interests of regulated firms). 
approvals of the past decade, ${ }^{214}$ as well as the Comptroller of the Currency's more recent Part V regulations, ${ }^{215}$ and, in many respects, offers a cleaner solution to the problem of segregating regulatory structures than did earlier attempts of forcing nontraditional activities, such as municipal securities operations, into separately organized divisions. ${ }^{216}$

Another noteworthy feature of recent reform proposals is the fact that its use of push-out strategies was fairly limited. Under many recent reform proposals, banks would not have to transfer all insurance and securities activities to separate legal entities. Rather, most insurance agency and securities brokerage activities could still be conducted within banks themselves, with direct supervision by the SEC and state insurance regulators. That is, these other activities would be governed by a fairly pure form of functional regulation. Distinguishing between agency activities on the one hand and principal and underwriter activities on the other is fully justified. The regulation of agency activities does not, for the most part, depend on capital requirements or substantial disclosure obligations that would conflict with basic bank regulation. Rather in the area of agency regulation, the primary emphasis is on policing the quality of interactions between the agent and its customer as well as ensuring the integrity and qualifications of the personnel. These supervisory functions can be superimposed fairly easily on depository institutions without substantial conflict with other regulatory functions. Accordingly, there is no need for a push-out strategy in these areas, and recent reform proposals have quite sensibly not imposed the requirement in these areas.

\section{c. The Special Problem of Holding Company Regulation}

A final noteworthy area of regulatory conflict concerns the alignment of holding company regulation in a system of functional regulation. As I have written elsewhere in greater detail, ${ }^{217}$ the primary purpose of financial holding company regulation is to supplement the supervision of a regulated entity by extending the supervisory umbrella to holding companies and other affiliated entities. In certain respects, holding company regulation reflects a lack of confidence in the adequacy of direct supervision of regulated firms,

214. See Securities Indus. Ass'n v. Board of Governors, 839 F.2d 47 (2d Cir. 1988), discussed in JACKSON \& SYMONS, supra note 1, at 1085-102.

215. See JACKSON \& SYMONS, supra note 1, at 292-93.

216. See Fein, supra note 193, at 100-04 (discussing earlier uses of separate divisions as forms of functional regulation).

217. See Howell E. Jackson, Regulation of Financial Holding Companies, in THE NEW PALGRAVE DICTIONARY OF LAW \& ECONOMICS (1998). 
and, as such, the intensity of holding company regulation differs from sector to sector in the financial services industry. One of the dilemmas of functional regulation is figuring out how to align differing systems of holding company regulation. Absent some accommodation, the most stringent system of holding company regulation-in the United States, that would be the Bank Holding Company Act-would trump all other more liberal regimes for organizations active in all sectors of the industry.

Financial reform proposals of the past year or so have approached the problem of aligning systems of holding company regulation with varying degrees of success. A common feature of several reform bills is a recognition that some accommodation must be made in the federal Bank Holding Company Act structure to prevent it from eclipsing or otherwise superceding the less onerous regulatory structures imposed on insurance and securities firm holding companies. For example, the Senate Banking Committee's bill of last September would have required the Federal Reserve Board to exclude insurance and securities affiliates from determining capital requirements for the bank holding company structure and also have mandated Board deference to other regulatory authorities in the area of examinations, reporting requirements, and various interpretations of law. ${ }^{218}$ While the bill generally retained the Federal Reserve Board as the umbrella regulator for financial holding companies, ${ }^{219}$ it encouraged the Board in various ways to exert its prerogatives in a manner respectful of the expertise of other regulatory authorities.

Less successful have been efforts to align the very liberal holding company regulation of unitary thrift holding companies, which currently face no activities restrictions or capital requirements, with those applicable to bank holding companies. Under a regime of pure functional regulation, one would expect to see these two regulatory systems largely aligned, as banks and thrifts have grown to be functionally quite similar. By the end of the last

218. See H.R. 10, 105th Cong. $\S \S 111-116$ (1998) (H.R. 10 as reported out of the Senate Banking Committee on September 21, 1998 as described in S. REP. NO. 105-336 (1998)).

219. The Senate bill provided for at least two instances in which other agencies would assume primary responsibility for holding company regulation. First, if the holding company in question was not engaged in "substantial nonbanking activities," the bill would have allowed the Board to transfer regulatory authority to the federal banking agency responsible for the organization's lead bank. See id. $\S 111$. In addition, for investment bank holding companies not otherwise subject to Federal Reserve Board supervision, the bill establishes that such institutions could elect to have the SEC serve as its holding company supervisor. See id. § 231. This new investment bank holding company structure creates a sort of parallelism between bank and securities firm holding companies, but it is unclear what its impact will be. The provision responds to problems faced by some investment banks engaged in certain foreign markets where local regulators require holding company supervision in the home country. Without an investment bank holding company structure in place, U.S. securities firms have reportedly had difficulty meeting these requirements. 
Congress, however, the consensus seems to have been to glaze over this problem by granting fairly liberal grandfather rights to existing unitary thrift holding companies, including those formed in the past year to exploit the possibility of such grandfathering privileges being granted. ${ }^{220}$ For grandfathered unitary thrift holding companies, the existing lax system of holding regulation would remain. For other depository institution holding companies, a more stringent regulatory structure would apply, threatening to create a rather substantial regulatory discontinuity between different classes of depository institutions and thus an incentive to convert various kinds of banks into grandfathered thrift institutions.

\section{CONCLUSION}

The division of our financial services industry into distinct spheres of regulatory control stems from fundamental differences in financial products and also from differing social goals underlying the regulation of each sector of the industry. The distinctions between sectors are not, however, sufficiently clear-cut to prevent the emergence of a relatively large gray area where the proper classification of particular products becomes a debatable proposition. In light of the ample incentives for both private parties and regulatory officials to exploit jurisdictional ambiguities and expand the area of definitional uncertainty, disputes over regulatory jurisdiction are inevitable and ubiquitous.

This Essay has attempted to explain both why disputes over regulatory classifications arise and how our legal system currently seeks to allocate jurisdiction in our multisectored financial services industry. The analysis presents a number of recurring definitional conventions that reformers have been drawing upon in their proposals to modernize our system of financial regulation. While these reformers often characterize their proposals as examples of functional regulation, closer inspection reveals that these proposals are often better understood as hybrid systems of regulatory classification, similar in many respects to our current regulatory structure. Moreover, the incentives and pressures that complicate our current system of financial classification will likely persist to bedevil whatever division of regulatory authority legislative reforms ultimately embrace.

220. See, e.g., id. § 401. 